Article

\title{
Ecological Risk Assessment of Potential Toxic Elements in Salt Marshes on the East Coast of the Red Sea: Differential Physiological Responses and Adaptation Capacities of Dominant Halophytes
}

\author{
Farag Ibraheem ${ }^{1,2, *(\mathbb{D})}$, Nawal Al-Hazmi ${ }^{1}$, Mohamed El-Morsy ${ }^{3,4}(\mathbb{D})$ and Ahmed Mosa ${ }^{5}(\mathbb{D})$ \\ 1 Biology/Chemistry Department, Al Qunfodah University College, Umm Al-Qura University, \\ Al Qunfodah 21912, Saudi Arabia; nehazmi@uqu.edu.sa \\ 2 Botany Department, Faculty of Science, Mansoura University, Mansoura 35516, Egypt \\ 3 Desert Research Center, Range Management Unit, Mataryia, Cairo 11753, Egypt; mhmorsy@uqu.edu.sa \\ 4 Deanship of Scientific Research, Umm Al-Qura University, Makkah Al Mukarramah 11715, Saudi Arabia \\ 5 Soils Department, Faculty of Agriculture, Mansoura University, Mansoura 35516, Egypt; \\ ahmedmosa@mans.edu.eg \\ * Correspondence: fllbraheem@uqu.edu.sa
}

Citation: Ibraheem, F.; Al-Hazmi, N.; El-Morsy, M.; Mosa, A. Ecological Risk Assessment of Potential Toxic Elements in Salt Marshes on the East Coast of the Red Sea: Differential Physiological Responses and Adaptation Capacities of Dominant Halophytes. Sustainability 2021, 13, 11282. https://doi.org/10.3390/ su132011282

Academic Editor: Adriana Najar-Rodriguez

Received: 31 August 2021 Accepted: 4 October 2021 Published: 13 October 2021

Publisher's Note: MDPI stays neutral with regard to jurisdictional claims in published maps and institutional affiliations.

Copyright: (c) 2021 by the authors. Licensee MDPI, Basel, Switzerland. This article is an open access article distributed under the terms and conditions of the Creative Commons Attribution (CC BY) license (https:// creativecommons.org/licenses/by/ $4.0 /)$.

\begin{abstract}
The impact of the mutual interactions between salinity and the phytoavailability of potential toxic elements (PTEs) on the adaptation of halophytes in their natural habitat is complex and far from clear. Herein, we aimed to evaluate salinity- and PTE-induced oxidative stress in selected halophytes and the antioxidant responses of these plants. For that, five salt marshes were selected, and the physiological responses of dominant halophytes (Tamarix nilotica, Heliotropium crispum, Zygophyllum coccineum, Halopeplus perfoliata, and Avicennia marina) were evaluated against the physicochemical features of their rhizosediments. The tested locations varied in their physicochemical properties and showed various levels of salinity stress and a low fertility status. Distinct variations in ten PTE concentrations were recognized among locations and within plants, with $\mathrm{Cr}$ and Co showing the highest ecological risk indices. The high levels of salinity and PTEs were associated with higher foliar levels of malondialdehyde, particularly in A. marina and Z. coccineum. The bio-concentration ratio revealed hyperaccumulating potentials of PTEs by the tested halophytes. Z. coccineum showed effective accumulation of $\mathrm{Co}, \mathrm{Fe}$, and $\mathrm{Pb}$, while $\mathrm{T}$. nilotica exhibited effective accumulation of $\mathrm{Cu}$, $\mathrm{Cd}$, and $\mathrm{Zn}$. H. perfoliate had higher accumulation of $\mathrm{Cr}$ and $\mathrm{Hg}$, whereas $A$. marina accumulated a significant amount of $\mathrm{Hg}, \mathrm{Cd}, \mathrm{Zn}$, and $\mathrm{Mn}$. H. crispum leaves accumulated the highest Ni levels among the tested halophytes. Altogether, our results highlight the potential risk of pollution of the tested areas with PTEs and the efficient physiological adaptation of each of the tested halophytes as a unique biological system. They also reflect the high capabilities of the tested halophytes as phytoextractors of their corresponding PTEs and their potential as efficient tools for phytoremediation of salt- and PTE-affected lands.
\end{abstract}

Keywords: salt marshes; salinity; halophytes; potential toxic elements; oxidative stress; phytoremediation

\section{Introduction}

Coastal and inland salt marshes are important ecological habitats with unique soil physicochemical properties and halophytic vegetation [1]. In such habitats, soils usually contain high levels of salinity along with other physicochemical properties that significantly impact metal phytoavailability and accessibility across biological systems. These soils also act as sinks for PTEs, which are significant environmental pollutants. These elements are usually released as a result of various anthropogenic activities such as industrial waste, domestic waste dumps, oil spilling, rapid urbanization, marine construction, and agricultural practices [2-5]. The eastern coast of the Red Sea in Saudi Arabia extends for about $1700 \mathrm{~km}$ 
from Yemen to the border with Jordan and represents a unique arid and semiarid habitat. The severe climatic conditions (high temperature, limited precipitation, and increased evapotranspiration), the oligotrophic nature of the soil, and the high potential release of PTEs from oil trading and other anthropogenic activities exacerbate the deleterious effects of salinity and PTEs on halophytes inhabiting these areas [6-8]. Such conditions highlight the potential risk of soil contamination and potentiate the importance of continuous monitoring of soil and plant responses in the region. Therefore, monitoring the levels of PTEs has been considered of great environmental, ecological, nutritional, and toxicological concern $[9,10]$.

In higher plants, high levels of salinity and heavy metals induce various detrimental effects on growth and physiological processes such as osmotic imbalance, ion toxicity, disruption of the carbon balance, nutrient deficiency, and oxidative stress [11-13]. Such detrimental effects restrict growth in salt marshes to halophytic plants which have natural capabilities to tolerate salinity levels from 40 to $200 \mathrm{mM} \mathrm{NaCl}$ or even more [14-16]. In addition, halophytes can take up and accumulate high levels of PTEs with various uptake/tolerance capacities $[12,16]$. These unique plants belong to various taxonomic plant families, and their tolerance capabilities depend on plant species, metal type/concentration, and growth stage [17]. Moreover, halophytes are successfully adapted to other abiotic stress conditions occurring simultaneously in their harsh environments [15]. To tolerate these severe conditions, halophytes employ numerous combinations of morphological and physiological adaptations [18]. At the leaf level, various halophytes have special structures such as trichomes, salt glands, or succulent tissues to sequester or alleviate toxic ions and thus balance ion concentrations in plant tissues $[19,20]$. They have also developed specific mechanisms for maintaining a balance between the generation of reactive oxygen species (ROS) and their detoxification mechanisms under salinity, PTEs, and their associated stresses in arid and semiarid habitats [21].

A common response among most halophytes is the generation of ROS, which is an indispensable consequence of any type of salinity- and PTE-induced stress such as water deficit, and ionic and osmotic stresses [16,22]. ROS are mainly produced as a result of a stress-induced reduction in the electron transport chain in both chloroplasts and mitochondria or as a consequence (particularly $\mathrm{H}_{2} \mathrm{O}_{2}$ ) of oxidation of glycolate to glyoxylic acid in peroxisomes [23,24]. In fact, $\mathrm{H}_{2} \mathrm{O}_{2}$ is the most stable among ROS with a half-life of minutes compared to $<1 \mu$ s for other ROS such as singlet oxygen $\left(\mathrm{O}_{2}\right)$, superoxide $\left(\mathrm{O}_{2}{ }^{\bullet}\right)$, and hydroxyl ions $\left(\mathrm{OH}^{\bullet}\right)$, and thus only $\mathrm{H}_{2} \mathrm{O}_{2}$ has the ability to diffuse among neighboring cellular components and cells $[25,26]$. In the presence of transition metals such as $\mathrm{Fe}, \mathrm{Cu}$, and $\mathrm{Mn}$, and through the Haber-Weiss and Fenton reactions, $\mathrm{H}_{2} \mathrm{O}_{2}$ can generate highly toxic hydroxyl radicals $\left(\mathrm{OH}^{\bullet}\right)$, which activates ion transport via the plasma membrane such as $\mathrm{Ca}^{2+}$ influx and $\mathrm{K}^{+}$efflux $[27,28]$. ROS act as stress sensors at their optimum cellular levels; however, beyond such levels they are toxicity inducers $[29,30]$. Their toxic effect occurs via induction of peroxidation of lipids in cellular membranes, protein denaturation, DNA damage, pigment breakdown, carbohydrate oxidation, and disturbance of enzyme activity $[27,31,32]$. In general, halophytes have developed an efficient antioxidant system that maintains cellular ROS levels below the phytotoxic threshold, which varies significantly among halophytes depending on their differential cellular tolerance against ROS [22]. Under increased salinity and other associated stresses, the antioxidant protective mechanisms can become insufficient to counter the oxidative damage [18]. For instance, photosynthesis is one of the most sensitive physiological processes to salinity- and PTEinduced ROS since the photosynthetic photosystem (PSI and PSII) reaction centers are the main sites for ROS production in chloroplasts $[33,34]$. Under salinity and other stresses, the level of ROS increases and the overall photosynthetic activity and, consequently, carbon assimilation decreases because of the detrimental effects of ROS on thylakoid membrane organization and the modulation of photosystem II (PSII) activity in chloroplasts [32]. Therefore, monitoring photosynthetic pigments and key photosynthetic products has been 
an effective biomarker in anticipating stress-induced events and their consequences on carbon assimilation at the organism level [35].

In the current investigation, the study area included five Saudi salt marshes on the east coast of the Red Sea which is a key maritime route for the world oil and goods trade. These salt marshes are directly and/or indirectly affected by pollutants derived from various anthropogenic activities developing along the Red Sea. In addition, the selected salt marshes are close to the oldest maritime port in Saudi Arabia (AlQunfodah port). These factors, along with the high salinity and hyperarid and oligotrophic environment would significantly affect the chemical features and the levels of PTEs in the soil of these salt marshes. Such effects have not been previously reported in the selected area. Interestingly, these salt marshes are inhabited by halophytes that thrive in such harsh conditions. The successful adaptation of these halophytes suggests that these plants might have a strong potential as phytoextractors of PTEs and thus provide efficient tools for phytoremediation. Little is known about both the impact of the above pollution-inducing factors on soil chemical features and their consequences on the growth and physiology of halophytic plants in the area. Therefore, these salt marshes provide a unique natural system to investigate the degree of the anthropogenic activity-induced contamination by PTEs such as $\mathrm{Cd}, \mathrm{Cr}, \mathrm{Co}$, $\mathrm{Cu}, \mathrm{Fe}, \mathrm{Hg}, \mathrm{Mn}, \mathrm{Ni}, \mathrm{Pb}$, and $\mathrm{Zn}$ and the differential physiological responses, if any, of the dominant halophytic plants in the area. In addition, the current study will shed light on the potential of these halophytes as phytoextractors of contaminant elements. Moreover, this study provides necessary knowledge for making future decisions on the management and conservation of the area. Therefore, the objectives of the current study were to: (i) study the physicochemical properties of five selected salt marsh soils located at various proximities to the eastern Red Sea coast (south Saudi Arabia), (ii) assess the potential contamination hazard of PTEs in soils of the studied locations and their accumulation in the dominant halophytes, and (iii) assess the impact of the mutual interaction between current rhizospheric soil conditions and possible PTE contamination on physiological responses of the dominant halophytes.

\section{Materials and Methods}

\subsection{Study Area and Description of Selected Plant Species}

Five salt marsh locations representative of the common environment of the Red Sea coast were selected and designated as L1, L2, L3, L4, and L5 according to their proximity to the coast. L1 and L5 were the farthest and the closest to the seacoast, respectively. From each location, the most dominant plant species was identified according to $[36,37]$ and used for downstream analysis. These plants belong to different taxonomic families and included Tamarix nilotica (Tamaricaceae), Heliotropium crispum (Boraginaceae), Zygophyllum coccineum (Zygophyllaceae), Halopeplus perfoliate (Amaranthaceae), and Avicennia marina (Acanthaceae). All these plants are perennials. Additionally, all these plants are chamaephytes, except for Tamarix nilotica, which has a phanerophyte life form.

\subsection{Collection of Plant and Soil Samples}

Five individual plants from each dominant species of interest in each location were selected, labeled, and guarded. Three replications of leaf samples were collected from each plant, washed thoroughly using sterilized water, and divided into two sets. Depending on the downstream analysis, samples were either dropped immediately in liquid $\mathrm{N}$ or brought on ice to the laboratory for oven drying $\left(70{ }^{\circ} \mathrm{C}\right.$ until constant weight) for elemental measurements. Corresponding rhizospheric soil samples were collected by uprooting plants, removal of course soil particles, and collection of soil particles that were tightly adhered to the root. The collected soil samples were stored in polyethylene bags, transferred to the laboratory, air dried at room temperature, sieved at $2 \mathrm{~mm}$, and stored for soil physical and chemical analysis. 


\subsection{Soil and Plant Elemental Analyses}

\subsubsection{Soil Analysis}

Soil physical and chemical analyses were carried out using standardized methods [38]: particle size distribution by sieve analysis [39], soil porosity calculation from values of bulk and solid phase densities, water holding capacity by the standardized gravimetric determination of soil moisture content, hydraulic conductivity by the Darcy equation, total concentration of calcium carbonate using the gasometric determination method after adding $\mathrm{HCl}$ solution $(6 \mathrm{M})$, soil $\mathrm{pH}$ value of 1:2.5 distilled water suspension using a Jenway $3505 \mathrm{pH} / \mathrm{mV} /$ Temperature Meter, and electrical conductivity of 1:2.5 soil/water extract by a HANNA (HI9835) EC meter. Water-soluble ions were determined in a soil/water extract: $\mathrm{Ca}^{2+}, \mathrm{Mg}^{2+}$, and $\mathrm{K}^{+}$using inductively coupled plasma (iCAP ${ }^{\mathrm{TM}} 7000$ Plus Series ICP-OES, Thermo Scientific ${ }^{\mathrm{TM}}$, Waltham, MA, USA), $\mathrm{Na}^{+}$using a Jenway PFP7 flame photometer, $\mathrm{CO}_{3}{ }^{2-}$ and $\mathrm{HCO}_{3}{ }^{-}$by titration with standardized $\mathrm{H}_{2} \mathrm{SO}_{4}$ solution, and $\mathrm{Cl}^{-}$by titration with standardized $\mathrm{AgNO}_{3}$ solution. Concentrations of total organic elements $(\mathrm{C}, \mathrm{H}, \mathrm{N}$, and S) were determined by a CHNS analyzer (Thermo Scientific Flash 2000). The available concentration of PTEs was determined by ICP in the extraction of diethylene tri-amine penta acetic acid (DTPA).

\subsubsection{Plant Elemental Analysis}

Dried leaf samples were ground to a homogenous fine powder and used for determination of organic and inorganic elements. Organic element $(\mathrm{C}, \mathrm{N}, \mathrm{H}$, and S) concentrations in dry biomass samples were determined following the dry combustion technique using a CHNS analyzer (Thermo Scientific Flash 2000). For determination of inorganic elements, oven-dried samples were digested using aqua regia solution $\left(\mathrm{HCl} / \mathrm{HNO}_{3}\right.$ mixture, 3:1 $\mathrm{v} / \mathrm{v}$ ) in a microwave digester (Milestone MLS $1200 \mathrm{Mega}$ ), and PTE concentrations were determined using ICP-OES.

\subsection{Ecological Risk Assessment}

\subsubsection{Geo-accumulation Index ( $\left.\mathrm{I}_{\text {geo }}\right)$}

The geo-accumulation index $\left(\mathrm{I}_{\text {geo }}\right)$ is widely used to evaluate the contamination degree of PTEs either in A or O horizons as referenced to their geochemical background values in carbonate rocks [40].

$$
\mathrm{I}_{\text {geo }}=\log _{2}\left[\frac{\mathrm{C}_{\mathrm{n}}}{1.5 \cdot \mathrm{B}_{\mathrm{n}}}\right]
$$

where $C_{n}$ is the concentration of PTEs in the rhizospheric soil layer, and $B_{n}$ is the geochemical background concentration of PTEs in the Earth's crust. The geochemical background values were multiplied by 1.5 in order to minimize the natural fluctuations in the lithologic variations [41]. The $I_{\text {geo }}$ index is categorized into six classes to interpret the corresponding contamination intensities of PTEs (Supplementary materials Table S1).

\subsubsection{Enrichment Factor $\left(\mathrm{E}_{\mathrm{f}}\right)$}

To quantify the potential anthropogenic impact on soil contamination, the enrichment factor $\left(\mathrm{E}_{\mathrm{f}}\right)$ of PTEs was calculated in relation to elements with a low variability of occurrence $(\mathrm{LV})$ as a reference in both the tested and geochemical background samples [42].

$$
E_{\mathrm{f}}=\frac{\left(\frac{C_{n}}{L V}\right)_{\text {Sample }}}{\left(\frac{C_{n}}{L V}\right)_{\text {Background }}}
$$

where $C_{n}$ is the PTE concentration in the soil, and LV is the reference element concentration in the examined environment $(\mathrm{Al})$.

Typical reference elements are $\mathrm{Al}, \mathrm{Fe}, \mathrm{Mn}$, and $\mathrm{Rb}$ according to the literature [43]. This investigation used $\mathrm{Al}$ as a reference lithogenic element based on its low vertical mobility and high stability in the rhizosphere. 


\subsubsection{The Contamination Factor $\left(\mathrm{C}_{\mathrm{F}}\right)$}

The contamination factor $\left(\mathrm{C}_{\mathrm{F}}\right)$ was quantified by dividing the PTE concentrations in the studied locations $\left(C_{x}\right)$ by the background values $\left(C_{b}\right)$ according to the equation adopted by [44].

$$
\mathrm{C}_{\mathrm{F}}=\frac{\mathrm{C}_{\mathrm{x}}}{\mathrm{C}_{\mathrm{b}}}
$$

The contamination factor $\left(\mathrm{C}_{\mathrm{F}}\right)$ consists of four classes as illustrated in Supplementary materials Table S1.

\subsubsection{Potential Ecological Risk Index $\mathrm{E}_{\mathrm{r}}^{\mathrm{i}}$}

This criterion was introduced to evaluate the contamination load according to the toxicity coefficient values of PTEs [44].

$$
\mathrm{E}_{\mathrm{r}}^{\mathrm{i}}=\mathrm{T}_{\mathrm{r}}^{\mathrm{i}} \times \frac{\mathrm{C}_{\mathrm{i}}}{\mathrm{C}_{0}}
$$

where $\mathrm{T}_{\mathrm{r}}^{\mathrm{i}}$ is the toxicity coefficient of PTEs $(\mathrm{Cd}=30, \mathrm{Cr}=2, \mathrm{Co}=5, \mathrm{Cu}=5, \mathrm{Fe}=1, \mathrm{Hg}=40$, $\mathrm{Mn}=1, \mathrm{Ni}=5, \mathrm{~Pb}=5$, and $\mathrm{Zn}=1), \mathrm{C}_{\mathrm{i}}$ is the concentration of PTEs in the investigated soil, and $\mathrm{C}_{0}$ is the background value of the PTEs.

\subsubsection{The Pollution Load Index (PLI)}

The integrated pollution load index (PLI), which has four classes (Supplementary materials Table S1), was introduced by [45] as the root of the contamination factor of PTEs to provide an understanding of their potential deteriorative impact.

$$
\mathrm{PLI}=\sqrt[n]{\mathrm{C}_{\mathrm{F} 1} \times \mathrm{C}_{\mathrm{F} 2} \times \ldots \ldots \times \mathrm{C}_{\mathrm{Fn}}}
$$

2.4.6. The Contamination Degree (CD) and the Modified Degree of Contamination (mCD)

These integrated indices were introduced by [44] to simplify the load of contamination according to the following equations:

$$
\begin{array}{r}
\mathrm{CD}=\sum_{\mathrm{i}=1}^{\mathrm{n}} \mathrm{C}_{\mathrm{F}}^{\mathrm{i}} \\
\mathrm{mCD}=\frac{\sum_{\mathrm{i}=1}^{\mathrm{n}} \mathrm{C}_{\mathrm{F}}^{\mathrm{i}}}{\mathrm{n}}
\end{array}
$$

where $C_{F}$ is the calculated contamination factor. The contamination levels of these indices are illustrated in Supplementary materials Table S1.

\subsection{Plant Physiological Analysis}

2.5.1. Determination of Oxidative Damage in Leaves

Oxidative damage in leaves was assessed via monitoring the levels of both hydrogen peroxide $\left(\mathrm{H}_{2} \mathrm{O}_{2}\right)$ and malondialdehyde (MDA). For $\mathrm{H}_{2} \mathrm{O}_{2}, 500 \mathrm{mg}$ of frozen leaf tissues was crushed into a fine powder in liquid nitrogen, homogenized in $5 \mathrm{~mL}$ cold potassium phosphate buffer (50 $\mathrm{mM}$ potassium phosphate, $1 \mathrm{mM}$ EDTA, $\mathrm{pH}$ 7.5), and centrifuged at $4000 \mathrm{rpm}$ for $15 \mathrm{~min}$ at $4{ }^{\circ} \mathrm{C}$. The supernatant was then collected and used for the determination of $\mathrm{H}_{2} \mathrm{O}_{2}$ spectrophotometrically using a hydrogen peroxide assay kit (Biodiagonistic, HP 25, Giza, Egypt) following the manufacturer's instructions. Leaf MDA concentration was determined spectrophotometrically as described previously [46] with slight modification. Quantities of $500 \mathrm{mg}$ of frozen leaf tissues were homogenized in $5 \mathrm{~mL}$ of $10 \%$ trichloroacetic acid $(w / v)$ and centrifuged at $4000 \mathrm{rpm}$ for $10 \mathrm{~min}$ at $4{ }^{\circ} \mathrm{C}$. Aliquots of $500 \mu \mathrm{L}$ of the supernatant were mixed with $500 \mu \mathrm{L}$ of $0.6 \%(w / v)$ thiobarbituric acid and the mixture was incubated at $95^{\circ} \mathrm{C}$ for $15 \mathrm{~min}$, cooled in an ice bath, and centrifuged at $4000 \mathrm{rpm}$ for $10 \mathrm{~min}$ at $4{ }^{\circ} \mathrm{C}$. The absorbance of the resultant pink color was measured at 
450,532 , and $600 \mathrm{~nm}$. The MDA content was estimated using the extinction coefficient of $155(\mathrm{nmol} / \mathrm{L} / \mathrm{cm})$ and expressed as $\mathrm{nmol} \mathrm{g}^{-1} \mathrm{DW}$.

\subsubsection{Estimation of Antioxidant Substances}

Flavonoids and phenolic compounds in $100 \mathrm{mg}$ of powdered leaves were extracted three times in acetone to remove chlorophyll, dried, and resuspended in distilled water. Total flavonoids were determined spectrophotometrically at $410 \mathrm{~nm}$ using $\mathrm{AlCl}_{3}$ and quercetin as a standard [47]. Total phenolics were determined spectrophotometrically at a wavelength of $760 \mathrm{~nm}$ using the Folin-Ciocalteu method and gallic acid as a standard [48]. The concentrations of total flavonoids and total phenolics were expressed as mg/g DWT.

\subsubsection{Determination of Photosynthetic Pigments}

Photosynthetic pigments were extracted by grinding $50 \mathrm{mg}$ of frozen leaves in cold $80 \%$ aqueous acetone, and the concentrations of chlorophyll a (Chl a), chlorophyll b (Chl b), and carotenoids (Cars) were determined spectrophotometrically at 663.2, 646.8, and $470.0 \mathrm{~nm}$ according to [49]. Pigment concentrations were expressed as mg/g FWT.

\subsubsection{Determination of Carbohydrate Fractions}

Quantities of $100 \mathrm{mg}$ powdered dry leaves were extracted with $80 \%$ ethanol, and the ethanolic extracts were completed to specific volumes and used for the spectrophotometric determination of total soluble sugars (TSS) and sucrose at $620 \mathrm{~nm}$ using anthrone reagent $[50,51]$. Carbohydrate fractions were calculated using standard curves of pure glucose and sucrose and expressed as $\mathrm{mg} / \mathrm{g}$ DWT.

\subsection{Quality Control and Statistical Analysis}

Chemical reagents of analytical grade (Merck-Darmstadt, Germany) were used without extra purification. Preparation of chemical solutions was carried out using deionized water (18.2 M $\Omega$ ) (Nanopure water, Barnstead). Soil and plant analyses were carried out by an ISO/IEC 17025 accredited laboratory to ensure data verification. All soil and plant analyses were carried out under constant temperature $\left(25 \pm 0.5^{\circ} \mathrm{C}\right)$ with appropriate replications, controls, and blanks. Certified soil reference materials (BIPEA, France) were used to optimize the quality control of soil analysis. The accuracy of organic element measurements was verified using the BBOT standard $\left(\mathrm{C}_{26} \mathrm{H}_{26} \mathrm{~N}_{2} \mathrm{SO}_{2} ; \mathrm{C}=72.52 \%, \mathrm{H}=6.09 \%\right.$, $\mathrm{N}=6.51 \%$, and $\mathrm{S}=7.44 \%$ ). In addition, the accuracy of inorganic element determination was verified using standard calibration solutions $\left(R^{2} \geq 0.99\right)$. The recovery values of elemental determination oscillated in the range between 93.25 and $103.35 \%$, and the precision of data was optimized through adjusting the maximum relative standard deviation (RSD) at $\leq 5 \%$. Limits of detection (LODs) for inorganic elements $\left(\mu \mathrm{g} \mathrm{L}^{-1}\right)$ were: As (33.12), $\mathrm{B}$ (25.32), Ba (26.52), Ca (95.2), Cd (53.43), Cr (31.75), Cu (20.76), Fe (46.82), Hg (23.54), $\mathrm{K}$ (26.7), Li (34.63), Mg (128.9), Mn (29.73), Ni (40.17), Pb (54.93), Ti (55.41), V (26.18), and Zn (40.95).

Standard deviations were calculated using Microsoft Excel software (version 2010, Microsoft Corporation, Redmond, Washington, DC, USA). Correlation analysis was performed using CoStat (Version 6.303, CoHort, Berkeley, CA, USA, 1998-2004) at significance levels of 0.05 and 0.01 to test the relationship among selected soil physicochemical characters and the extractability potentials of PTEs.

\section{Results and Discussion}

Despite the harsh climatic conditions and the unique location of the selected salt marshes in the current study (proximity to the oldest port in Saudi Arabia, location on the world's key maritime route of the oil and goods trade, intensive construction, and industrial projects), very little information about the extent of possible soil pollution induced by the above factors and its consequences on the physiology of the dominant plants is available. Therefore, the impact of the interplay among the above factors on 
chemical properties and the levels of PTEs in soils of these salt marshes was investigated. In addition, the physiological responses of the dominant plants were tested and compared. Further, the phytoremediation potential of the dominant halophytes was monitored to extend the ecological significance of the study.

\subsection{Soil Physicochemical Analysis}

All soils in the investigated locations were sandy in texture (Typic Torripsamment) according to the USDA soil taxonomy [52]. Particle size distribution comprised 60-66\% coarse sand fraction in $\mathrm{L}_{1}-\mathrm{L}_{4}$ (Table 1$)$. The coarse sand fraction was lower in $\mathrm{L}_{5}(38.4 \%)$. Contrarily, its silt and clay fraction was the highest among the studied locations (10.7\%). The high coarse sand fraction increased soil porosity $(\sim 45.1 \%)$ and the macro-pore volume of the soil matrix. Therefore, the studied soils may not impose significant restrictions on the root growth of the tested halophytes. The soil organic matter content in most locations was very low and was below the detection limit in $L_{1}$ and $L_{2}$. This low organic matter content is mainly attributed to the fast decomposition of soil organic matter due to the high temperature, low precipitation, and high aeration in the soil matrix [53]. Unlike other studied locations, the coastal location $\left(\mathrm{L}_{5}\right)$ recorded the highest organic matter content $(2.69 \%)$, which is mainly attributed to the belowground accumulation of plant litter derived from mangrove forests under waterlogged conditions. In addition, this coastal location might accrete plant litter and solutes as the sea level rises, which provides a continuous accumulation and burial of soil organic matter [54]. The water holding capacity of soils in most locations was very low (32-35\%) due to the low colloidal content (clay and organic matter, in particular) in the soil matrix $[55,56]$. However, the higher content of soil organic matter in $\mathrm{L}_{5}$ improved its water supply potential and maximized its water holding capacity $(40.12 \%)$. This finding is further supported by the data of soil hydraulic conductivity, which show high values in the $\mathrm{L}_{1}-\mathrm{L}_{4}$ locations $\left(13.39-16.76 \mathrm{~cm} \mathrm{ha}^{-1}\right)$. Meanwhile, $\mathrm{L}_{4}$ and $\mathrm{L}_{5}$ showed lower conductivity values (2.99 and $0.79 \mathrm{~cm} \mathrm{ha}^{-1}$, respectively). The total concentration of $\mathrm{CaCO}_{3}$ varied among locations (Table $1 ; 0.55,1.25$, and $2.44 \%$ for minimum, median, and maximum concentrations, respectively). The low $\mathrm{CaCO}_{3}$ concentrations in $\mathrm{L}_{4}$ and $\mathrm{L}_{5}$ ( 0.79 and $0.55 \%$, respectively) could be attributed to the continuous dissolution by the tidal currents. The studied soils were all alkaline in nature with $\mathrm{pH}$ values ranging from 7.76 to 8.44 (Table 1 ). Salinity values varied greatly among locations $\left(2.48-12.14 \mathrm{dSm}^{-1}\right.$ ) with noticeable higher values in the coastal locations $\left(\mathrm{L}_{3}, \mathrm{~L}_{4}\right.$, and $\left.\mathrm{L}_{5}\right)$. The high EC values in the tested arid saline habitats are shaped by interplay among metrological data in such arid conditions (high temperature, low precipitation, and high rate of evaporation, Supplementary Materials Table S2) along with the high salt contents derived from the Red Sea. The increased rate of evaporation that exceeds freshwater inputs can lead to hypersaline conditions due to the high accumulation of salts in the soil matrix [54]. Soil salinity in low-lying coastal locations was significantly higher than other locations due to the periodic inundation by the tidal water. However, other non-coastal locations might receive freshwater inputs from precipitation that can leach the accumulated salts. Watersoluble $\mathrm{CO}_{3}{ }^{2-}$ was not detected since calcium carbonate was the predominant carbonate form in the studied locations. However, $\mathrm{Cl}^{-}$and $\mathrm{HCO}_{3}{ }^{-}$were the major anions in soils at different locations (Table 1). The $\mathrm{HCO}_{3}{ }^{-}$concentration was higher than that of $\mathrm{Cl}^{-}$in $\mathrm{L}_{1}$ and $\mathrm{L}_{2}$. The concentration of $\mathrm{Cl}^{-}$anions, however, was higher in the other locations. These results are in harmony with the data of soil salinity, which showed higher EC values in $\mathrm{L}_{3}, \mathrm{~L}_{4}$, and $\mathrm{L}_{5}$ since the chlorinated soil solutions often induce a higher ionic strength than bicarbonated solutions [57]. The median concentration of dominant cations was ranked as $\mathrm{Ca}^{2+}>\mathrm{Na}^{+}>\mathrm{Mg}^{2+}>\mathrm{K}^{+}$. 
Table 1. Some Physical and Chemical Analyses of the Experimental Soils.

\begin{tabular}{|c|c|c|c|c|c|c|c|c|c|c|c|c|c|c|c|c|c|c|c|}
\hline \multirow{3}{*}{ Locations } & \multicolumn{10}{|c|}{ Soil Physical Properties } & \multicolumn{9}{|c|}{ Soil Chemical Properties } \\
\hline & \multicolumn{7}{|c|}{ Particle Size Distribution (\%) } & \multicolumn{2}{|c|}{ Porosity WHC } & \multirow{2}{*}{$\begin{array}{c}\mathrm{HC} \\
\begin{array}{c}\mathrm{K} \\
\mathrm{cm} \\
\mathrm{h}^{-1}\end{array}\end{array}$} & \multirow{2}{*}{$\begin{array}{c}\text { EC } \\
\underset{m^{-1}}{d s}\end{array}$} & \multirow[t]{2}{*}{$\mathrm{pH}$} & \multicolumn{2}{|c|}{$\mathrm{CaCO}_{3}$} & \multicolumn{5}{|c|}{$\begin{array}{l}\text { Water Soluble Cations and Anions } \\
\text { Concentration }\left(\mathrm{cmol} \mathrm{kg}^{-1}\right)\end{array}$} \\
\hline & $\begin{array}{l}2-0- \\
1.85\end{array}$ & $\begin{array}{l}1.85- \\
0.425\end{array}$ & $\begin{array}{l}0.425- \\
0.25\end{array}$ & $\begin{array}{l}0.25- \\
0.125\end{array}$ & $\begin{array}{l}0.125- \\
0.075\end{array}$ & $<0.075$ & Texture & e $(\%)$ & $(\%)$ & & & & $(\%)$ & $\mathrm{HCO}_{3}$ & $\mathrm{Cl}^{-}$ & $\mathrm{Ca}^{2+}$ & $\mathrm{Mg}^{2+}$ & $\mathbf{K}^{+}$ & $\mathrm{Na}^{+}$ \\
\hline $\mathrm{L}_{1}$ & 2.59 & 2.21 & 6.09 & 55.01 & 26.73 & 7.37 & Sandy & $\begin{array}{c}40.05 \\
\pm \\
3.66\end{array}$ & $\begin{array}{c}32.08 \\
\pm \\
2.85\end{array}$ & $\begin{array}{c}13.39 \\
\pm \\
1.29\end{array}$ & $\begin{array}{c}3.74 \\
\pm \\
0.34\end{array}$ & $\begin{array}{c}8.14 \\
\pm \\
0.4\end{array}$ & $\begin{array}{c}2.44 \\
\pm \\
0.28\end{array}$ & $\begin{array}{c}6.25 \\
\pm \\
0.51\end{array}$ & $\begin{array}{c}4.46 \\
\pm \\
0.41\end{array}$ & $\begin{array}{c}2.91 \\
\pm \\
0.33\end{array}$ & $\begin{array}{c}0.72 \\
\pm \\
0.17\end{array}$ & $\begin{array}{c}0.32 \\
\pm \\
0.07\end{array}$ & $\begin{array}{c}0.89 \\
\pm \\
0.13\end{array}$ \\
\hline $\mathrm{L}_{2}$ & 3.04 & 5.21 & 6.88 & 49.65 & 30.66 & 4.57 & Sandy & $\begin{array}{c}48.15 \\
\pm \\
4.51\end{array}$ & $\begin{array}{c}30.12 \\
\pm \\
2.56\end{array}$ & $\begin{array}{c}13.65 \\
\pm \\
1.30\end{array}$ & $\begin{array}{c}2.46 \\
\pm \\
0.25\end{array}$ & $\begin{array}{c}8.04 \\
\pm \\
0.32\end{array}$ & $\begin{array}{c}1.87 \\
\pm \\
0.25\end{array}$ & $\begin{array}{c}6.17 \\
\pm \\
0.50\end{array}$ & $\begin{array}{c}2.90 \\
\pm \\
0.29\end{array}$ & $\begin{array}{c}3.13 \\
\pm \\
0.39\end{array}$ & $\begin{array}{c}0.74 \\
\pm \\
0.14\end{array}$ & $\begin{array}{c}1.45 \\
\pm \\
0.22\end{array}$ & $\begin{array}{c}0.16 \\
\pm \\
0.02\end{array}$ \\
\hline $\mathrm{L}_{3}$ & 2.04 & 2.37 & 4.14 & 57.23 & 29.70 & 4.53 & Sandy & $\begin{array}{c}39.29 \\
\pm \\
3.73 \\
43.74\end{array}$ & $\begin{array}{c}31.05 \\
\pm \\
2.76 \\
35.19\end{array}$ & $\begin{array}{c}16.76 \\
\pm \\
2.15 \\
2.99\end{array}$ & $\begin{array}{c}9.94 \\
\pm \\
1.04 \\
1210\end{array}$ & $\begin{array}{c}7.71 \\
\pm \\
0.33 \\
7.96\end{array}$ & $\begin{array}{c}1.25 \\
\pm \\
0.09 \\
0.79\end{array}$ & $\begin{array}{c}9.75 \\
\pm \\
0.86 \\
4.20\end{array}$ & $\begin{array}{c}22.42 \\
\pm \\
2.15 \\
53.38\end{array}$ & $\begin{array}{c}5.10 \\
\pm \\
0.52 \\
4.35\end{array}$ & $\begin{array}{c}2.10 \\
\pm \\
0.34 \\
4.68\end{array}$ & $\begin{array}{c}0.87 \\
\pm \\
0.15 \\
1.30\end{array}$ & $\begin{array}{c}2.50 \\
\pm \\
0.33 \\
7.58\end{array}$ \\
\hline $\mathrm{L}_{4}$ & 8.35 & 9.69 & 6.04 & 40.23 & 31.47 & 4.21 & Sandy & $\stackrel{ \pm}{ \pm}$ & $\begin{array}{l} \pm \\
3.35\end{array}$ & \pm .15 & $\stackrel{ \pm}{ \pm}$ & $\begin{array}{l} \pm \\
0.33\end{array}$ & \pm .11 & $\stackrel{ \pm}{ \pm}$ & $\begin{array}{c} \pm \\
4.28\end{array}$ & $\begin{array}{l} \pm \\
\pm .40\end{array}$ & $\begin{array}{l} \pm \\
0.61\end{array}$ & $\begin{array}{c} \pm \\
\pm .24\end{array}$ & \pm .52 \\
\hline $\mathrm{L}_{5}$ & 3.94 & 11.01 & 8.42 & 14.89 & 41.16 & 20.58 & Sandy & $\begin{array}{c}49.89 \\
\pm \\
4.55\end{array}$ & $\begin{array}{c}40.12 \\
\pm \\
3.70\end{array}$ & $\begin{array}{c}0.79 \\
\pm \\
0.08\end{array}$ & $\begin{array}{c}9.92 \\
\pm \\
1.02\end{array}$ & $\begin{array}{c}8.27 \\
\pm \\
0.41\end{array}$ & $\begin{array}{c}0.55 \\
\pm \\
0.05\end{array}$ & $\begin{array}{c}6.07 \\
\pm \\
0.62\end{array}$ & $\begin{array}{c}22.04 \\
\pm \\
2.30\end{array}$ & $\begin{array}{c}1.58 \\
\pm \\
0.21\end{array}$ & $\begin{array}{c}3.04 \\
\pm \\
0.49\end{array}$ & $\begin{array}{c}1.19 \\
\pm \\
0.19\end{array}$ & $\begin{array}{c}2.81 \\
\pm \\
0.29\end{array}$ \\
\hline
\end{tabular}

Values are the average values of three replications \pm standard deviations. $\mathrm{L}_{1}$ (soil colonized with $T$. nilotica), $\mathrm{L}_{2}$ (soil colonized with $H$. crispum), $\mathrm{L}_{3}$ (soil colonized with Z. coccineum), $\mathrm{L}_{4}$ (soil colonized with $H$. perfoliata), and $\mathrm{L}_{5}$ (soil colonized with $A$. marina): WHC (water holding capacity), HC (hydraulic conductivity), and EC (electrical conductivity). The organic carbon concentration in the soil was the highest in $\mathrm{L}_{5}(1.56 \%)$ taking into consideration its relatively higher organic matter content (Table 2). This carbon content was very low in $\mathrm{L}_{3}$ and $\mathrm{L}_{4}(0.022$ and $0.086 \%$, respectively), and it was below the detection limit in $\mathrm{L}_{1}$ and $\mathrm{L}_{2}$. The nitrogen concentration in $\mathrm{L}_{5}$ was very low $(0.081 \%)$; however, it was not detected in the other locations, which may be ascribed to the general deficiency of $\mathrm{N}$ in seawater [58]. Likewise, the sulfur concentration was below the detection limit in all studied locations. On the contrary, the hydrogen concentration was the highest among the other organic elements $(0.211-0.515 \%)$. The relatively high hydrogen content might be derived from the soil-bound water. This finding is supported by the data of the water holding capacity of the soils (Table 1). The concentrations of most plant nutrients reflected the low fertility status of the soil, and the urgent need to add fertilizer application for improving the growth and phytoremediation potential of the tested halophytes or for the potential cultivation by economic crops [59]. This low nutrient content is mainly attributed to the low colloidal content, which minimized the nutrient supply potentials of the soil $[60,61]$. The available phosphorus concentration in all locations was very low $\left(6.91-9.20 \mathrm{mg} \mathrm{kg}^{-1}\right)$ and insufficient to meet the adequate phosphorus supply in light soils (50-85 $\left.\mathrm{mg} \mathrm{kg}^{-1}\right)$ [62] which could be attributed to the high soil $\mathrm{pH}$ that reduces phosphorus availability [63]. Likewise, the available calcium concentration was below the adequate concentration in light soils (3000-4000 $\mathrm{mg} \mathrm{kg}^{-1}$ ) [62]. In this regard, the $\mathrm{Ca}^{2+}$ concentration in $\mathrm{L}_{5}$ was the lowest $\left(630.93 \mathrm{mg} \mathrm{kg}^{-1}\right)$, presumably due to the continuous dissolution of calcium salts by the inflow of seawater during tidal entry. Concentrations of $\mathrm{K}^{+}$and $\mathrm{Mg}^{2+}$ were relatively high taking into consideration marine inputs by different mechanisms (e.g., seawater spray from winds, tidal surges, and seawater intrusion into shallow groundwater). The potassium concentration in $\mathrm{L}_{1}$ was $124.67 \mathrm{mg} \mathrm{kg}^{-1}$, and this level is inadequate for sufficient plant nutrition (200-400 $\mathrm{mg} \mathrm{kg}^{-1}$ ) [62]. This concentration, however, varied among other locations between 351.27 and $593.81 \mathrm{mg} \mathrm{kg}^{-1}$. On the other hand, the $\mathrm{Mg}^{2+}$ concentration in $\mathrm{L}_{1}, \mathrm{~L}_{2}$, and $\mathrm{L}_{3}$ was inadequate for plant nutrition $\left(<600-800 \mathrm{mg} \mathrm{kg}^{-1}\right)$. Meanwhile, the $\mathrm{L}_{4}$ and $\mathrm{L}_{5}$ locations showed adequate concentrations (1119.6 and 737.76, respectively). 
Table 2. Total Organic and Available Nutrient Concentrations in the Experimental Soils.

\begin{tabular}{|c|c|c|c|c|c|c|c|c|c|c|}
\hline \multirow{2}{*}{ Locations } & \multicolumn{4}{|c|}{ Total Organic Elements Concentration (\%) } & \multirow{2}{*}{ OM (\%) } & \multicolumn{5}{|c|}{ Available Nutrients Concentration (mg kg $\left.{ }^{-1}\right)$} \\
\hline & $\mathrm{C}$ & $\mathbf{N}$ & $\mathbf{H}$ & $\mathbf{S}$ & & $\mathbf{P}$ & $\mathbf{K}$ & $\mathrm{Ca}$ & Mg & $\mathbf{N a}$ \\
\hline $\mathrm{L}_{1}$ & N.D & N.D & $\begin{array}{c}0.211 \pm \\
0.0200\end{array}$ & N.D & N.D & $\begin{array}{c}3.21 \pm \\
0.12\end{array}$ & $\begin{array}{c}124.67 \pm \\
11.1\end{array}$ & $\begin{array}{c}1162.19 \\
\pm 108\end{array}$ & $\begin{array}{c}169.35 \pm \\
3.3\end{array}$ & $\begin{array}{l}204.60 \\
\pm 24.9\end{array}$ \\
\hline $\mathrm{L}_{2}$ & N.D & N.D & $\begin{array}{c}0.260 \pm \\
0.0245\end{array}$ & N.D & N.D & $\begin{array}{c}6.89 \pm \\
0.41\end{array}$ & $\begin{array}{c}593.81 \pm \\
50.8\end{array}$ & $\begin{array}{c}1250.90 \\
\pm 116\end{array}$ & $\begin{array}{c}178.61 \pm \\
0.3\end{array}$ & $\begin{array}{l}35.81 \\
\pm 3.5\end{array}$ \\
\hline $\mathrm{L}_{3}$ & $\begin{array}{c}0.0215 \pm \\
0.0016\end{array}$ & N.D & $\begin{array}{c}0.277 \pm \\
0.0221\end{array}$ & N.D & $\begin{array}{c}0.037 \pm \\
0.0028\end{array}$ & $\begin{array}{c}7.07 \pm \\
0.74\end{array}$ & $\begin{array}{c}351.27 \pm \\
30.1\end{array}$ & $\begin{array}{c}2039.95 \\
\pm 197\end{array}$ & $\begin{array}{c}500.53 \pm \\
44.4\end{array}$ & $\begin{array}{l}575.85 \\
\pm 70.2\end{array}$ \\
\hline $\mathrm{L}_{4}$ & $\begin{array}{c}0.0858 \pm \\
0.0076\end{array}$ & N.D & $\begin{array}{c}0.551 \pm \\
0.0434\end{array}$ & N.D & $\begin{array}{c}0.148 \pm \\
0.0131\end{array}$ & $\begin{array}{c}8.90 \pm \\
0.98\end{array}$ & $\begin{array}{c}541.44 \\
48.5\end{array}$ & $\begin{array}{c}1740.83 \\
\pm 173\end{array}$ & $\begin{array}{c}1119.6 \pm \\
96.4\end{array}$ & $\begin{array}{r}1743.97 \\
\pm 167.4\end{array}$ \\
\hline $\mathrm{L}_{5}$ & $\begin{array}{c}1.5600 \pm \\
0.0818\end{array}$ & $\begin{array}{c}0.081 \pm \\
0.008\end{array}$ & $\begin{array}{c}0.427 \pm \\
0.0365\end{array}$ & N.D & $\begin{array}{c}2.690 \pm \\
0.1411\end{array}$ & $\begin{array}{c}9.13 \pm \\
0.81\end{array}$ & $\begin{array}{c}496.00 \pm \\
43.9\end{array}$ & $\begin{array}{c}630.93 \\
\pm 59\end{array}$ & $\begin{array}{c}737.76 \pm \\
70.0\end{array}$ & $\begin{array}{l}646.46 \\
\pm 59.9\end{array}$ \\
\hline
\end{tabular}

\subsection{Soil Available Concentrations of PTEs and Their Correlation Matrix ( $r$ ) with Soil} Physicochemical Properties

The median, maximum, and minimum values of soil available PTE concentrations are illustrated in box-and-whisker diagrams (Figure 1). The median values of PTE concentrations ( $\mathrm{mg} \mathrm{kg}^{-1}$ ) were ordered as follows: $\mathrm{Mn}$ (19.83), $\mathrm{Fe}(11.21), \mathrm{Pb}(3.48), \mathrm{Cu}(2.10)$, $\mathrm{Zn}$ (1.62), Hg (1.09), Cr (0.60), Co (0.45), Ni (0.36), and Cd (0.04). Distinct variations in PTE concentrations were recognized between the studied locations (Figure. 1). Among locations, $\mathrm{L}_{4}$ showed the highest concentrations of $\mathrm{Cd}\left(0.069 \mathrm{mg} \mathrm{kg}^{-1}\right), \mathrm{Co}\left(0.590 \mathrm{mg} \mathrm{kg}^{-1}\right)$, $\mathrm{Cu}\left(3.764 \mathrm{mg} \mathrm{kg}^{-1}\right)$, and $\mathrm{Pb}\left(4.654 \mathrm{mg} \mathrm{kg}^{-1}\right)$. Meanwhile, $\mathrm{L}_{3}$ exhibited the highest concentrations of $\mathrm{Cr}\left(0.783 \mathrm{mg} \mathrm{kg}^{-1}\right), \mathrm{Hg}\left(1.257 \mathrm{mg} \mathrm{kg}^{-1}\right), \mathrm{Mn}\left(40.697 \mathrm{mg} \mathrm{kg}^{-1}\right)$, and $\mathrm{Zn}$ $\left(8.475 \mathrm{mg} \mathrm{kg}^{-1}\right)$. The high levels of PTEs in these two locations may be attributed to their proximity to a dumping area.
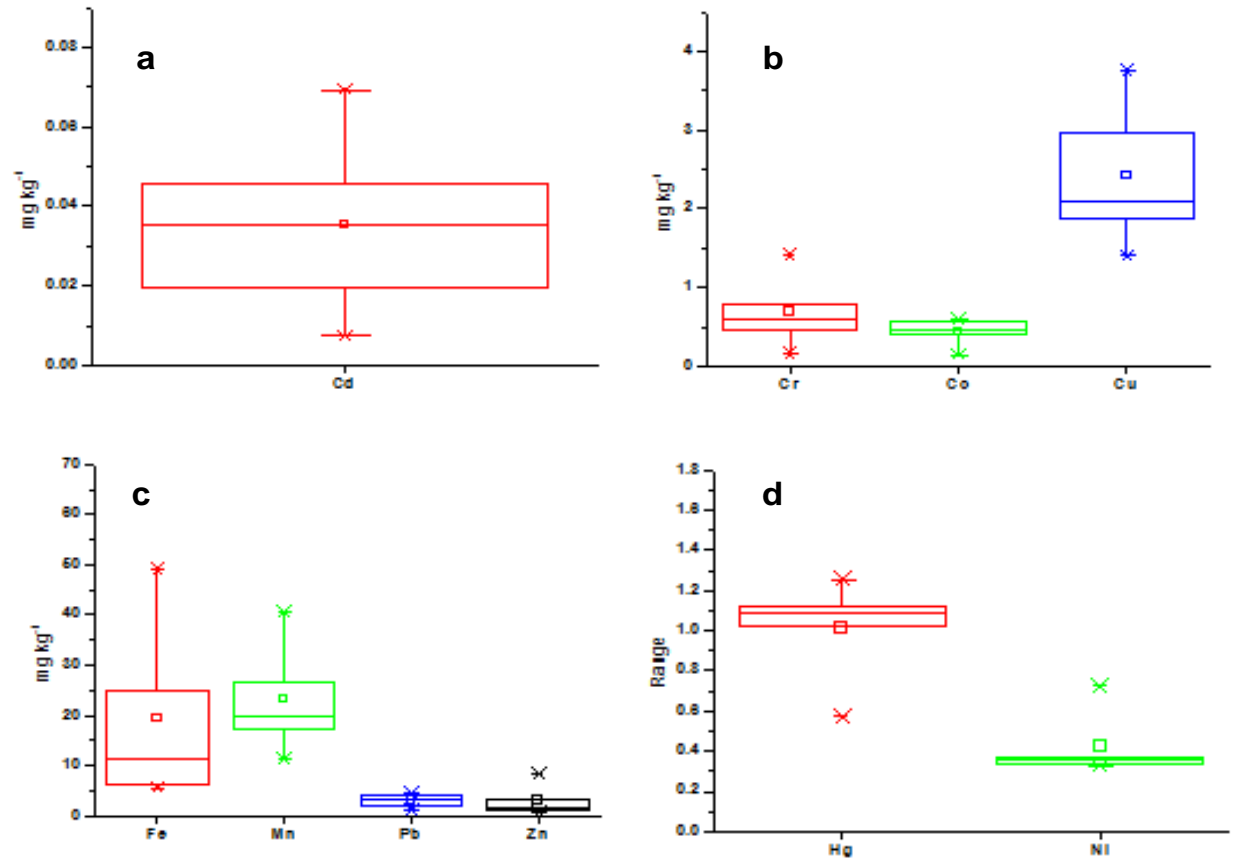

Figure 1. Available concentrations of PTEs $\left(\mathrm{mg} \mathrm{kg}^{-1}\right)$ in soil at different locations. The box chart is symbolized by the median (center line), mean (dot), lower and upper quartiles (the lower and upper borders of the box, respectively), and whiskers-error bars (the minimum and maximum values): (a) cadmium, (b) chromium, cobalt, and copper, (c) iron, manganese, lead, and zinc, and (d) mercury and nickel.

Pearson's correlation was applied to illustrate correlations between the available concentrations of PTEs and some specific soil physicochemical properties (Table 3). The correlation between PTEs and soil cations $\left(\mathrm{Ca}^{2+}, \mathrm{Mg}^{2+}, \mathrm{K}^{+}\right.$, and $\left.\mathrm{Na}^{+}\right)$was calculated based 
on the available forms of these cations (not the water-soluble form) to be consistent with the DTPA-extractable PTEs.

Table 3. Correlation Matrix (r) Between Soil Physicochemical Properties and Available Concentrations of PTEs, $\mathrm{n}=15$.

\begin{tabular}{|c|c|c|c|c|c|c|c|c|c|c|c|}
\hline PTEs & $\begin{array}{l}\text { Silt and Clay } \\
\text { Fraction } \\
(\%)\end{array}$ & $\begin{array}{c}\text { Organic } \\
\text { Matter } \\
(\%)\end{array}$ & $\begin{array}{c}E C \\
\left(\mathrm{dS} \mathrm{m}^{-1}\right)\end{array}$ & $\mathrm{pH}$ & $\underset{(\%)}{\mathrm{CaCO}_{3}}$ & $\begin{array}{l}\mathrm{Ca}^{2+} \\
\left(\mathrm{cmol}^{2}\right. \\
\left.\mathrm{kg}^{-1}\right)\end{array}$ & $\begin{array}{l}\mathrm{Mg}^{2+} \\
\left(\mathrm{cmol}^{-1}\right. \\
\left.\mathrm{kg}^{-1}\right)\end{array}$ & $\begin{array}{c}\mathrm{K}^{+} \\
(\mathrm{cmol} \\
\left.\mathrm{kg}^{-1}\right)\end{array}$ & $\begin{array}{l}\mathrm{Na}^{+} \\
\left(\mathrm{cmol}^{2}\right. \\
\left.\mathrm{kg}^{-1}\right)\end{array}$ & $\begin{array}{c}\mathrm{HCO}_{3}^{-} \\
\left(\mathrm{cmol}^{-}\right. \\
\mathrm{kg}^{-1} \text { ) }\end{array}$ & $\begin{array}{l}\mathrm{Cl}^{-} \\
\left(\mathrm{cmol}^{-}\right. \\
\left.\mathrm{kg}^{-1}\right)\end{array}$ \\
\hline $\mathrm{Cd}$ & -0.21 & $-0.62 *$ & 0.02 & -0.14 & 0.23 & 0.39 & 0.28 & -0.01 & $0.53 *$ & $-0.63 *$ & 0.44 \\
\hline $\mathrm{Cr}$ & $-0.79^{* *}$ & -0.30 & $-0.64 *$ & 0.08 & $0.84^{* *}$ & -0.10 & $-0.79 * *$ & $-0.90^{* *}$ & -0.71 * & 0.39 & $-0.73^{* *}$ \\
\hline Co & $-0.60 *$ & $-0.87^{* *}$ & 0.17 & $-0.83^{* *}$ & 0.22 & $0.94^{* *}$ & 0.12 & -0.17 & 0.37 & 0.17 & 0.37 \\
\hline $\mathrm{Cu}$ & 0.28 & -0.14 & $0.83 * *$ & $-0.58 *$ & $-0.66^{*}$ & $0.67 *$ & $0.84 * *$ & 0.43 & $0.88^{* *}$ & -0.10 & $0.92 * *$ \\
\hline $\mathrm{Fe}$ & -0.27 & 0.15 & -0.32 & 0.60 * & 0.47 & -0.51 & -0.31 & -0.78 ** & -0.26 & -0.20 & -0.34 \\
\hline $\mathrm{Hg}$ & $-0.84^{* *}$ & $-0.94 * *$ & -0.14 & $-0.81 * *$ & 0.51 * & $0.86^{* *}$ & -0.24 & -0.36 & 0.01 & 0.37 & 0.01 \\
\hline $\mathrm{Mn}$ & 0.56 * & -0.60 * & 0.01 & $-0.93^{* *}$ & 0.14 & 0.82 ** & -0.23 & -0.02 & -0.15 & $0.77^{* *}$ & -0.07 \\
\hline $\mathrm{Ni}$ & -0.63 * & -0.29 & -0.43 & 0.26 & $0.73^{* *}$ & -0.15 & -0.44 & -0.89 ** & -0.28 & -0.07 & -0.37 \\
\hline $\mathrm{Pb}$ & $0.73^{* *}$ & 0.17 & 0.35 & 0.05 & $-0.62 *$ & 0.01 & $0.62 *$ & $0.95 * *$ & 0.54 * & $-0.56^{*}$ & $0.56^{*}$ \\
\hline $\mathrm{Zn}$ & -0.38 & -0.38 & 0.43 & $-0.94^{* *}$ & -0.18 & $0.86^{* *}$ & 0.14 & -0.07 & 0.19 & $0.75^{* *}$ & 0.27 \\
\hline
\end{tabular}

The symbols $\left({ }^{*}\right.$ and ${ }^{* *}$ ) refer to the degree of significant correlation at confident levels of 0.05 and 0.01 , respectively.

$C d$ : A significant correlation $(\mathrm{r}=-0.62, p<0.05)$ was recorded between the available $\mathrm{Cd}^{2+}$ concentration and soil organic matter content given the high tendency of labile $\mathrm{Cd}^{2+}$ toward bonding with organic matter in immobile forms [64]. Additionally, a positive significant correlation $(\mathrm{r}=0.53)$ was noticed with $\mathrm{HCO}_{3}{ }^{-}$ions. According to [65], $\mathrm{Cd}$ predominantly exists in the form of $\mathrm{CdHCO}_{3}$ in alkaline soils, and higher concentrations than the background values are signals for anthropogenic inputs.

$\mathrm{Cr}$ : A negative significant correlation $(\mathrm{r}=-0.79, p<0.01)$ was noticed between $\mathrm{Cr}$ ions and the silt and clay fraction. According to [66], the particle size distribution of soil significantly affects the extractability/leachability, and thereby the bioaccessibility, of $\mathrm{Cr}(\mathrm{VI})$ ions in soil based on the variation of the distribution factor among different soil size fractions $(0.7,0.79,1.35$, and 1.6 for coarse sand, medium sand, fine sand, and silt-clay, respectively). Negative correlations were also recorded with $\mathrm{Ca}^{2+}(-0.79, p<0.01), \mathrm{K}^{+}$ $(-0.90 p<0.01)$, and $\mathrm{Na}^{+}(-0.69 p<0.05)$ ions. The high concentration of these cations might reduce the extractability of $\mathrm{Cr}(\mathrm{VI})$ ions through increasing their binding capacity by the colloidal phase via cation bridging formations with active sorption sites [67]. These colloidal-chromate complexes were stable and showed low extractability compared to most of the other PTEs [68]. In addition, negative correlations were recorded with EC $(-0.64, p<0.05)$ and $\mathrm{Cl}^{-}$ions $(-0.73, p<0.01)$. High values of ionic strength might lead to an increase in the Debye-Huckel screening influence, thereby reducing the electrostatic interaction between active sorption sites and $\mathrm{Cr}(\mathrm{VI})$ ions [69]. Reducing the affinity between the sorbent and sorbate might increase the extractability of $\mathrm{Cr}(\mathrm{VI})$ ions. Furthermore, the competition between $\mathrm{Cr}(\mathrm{VI})$ and $\mathrm{Cl}^{-}$ions onto sorption sites might reduce the binding capacity of $\mathrm{Cr}(\mathrm{VI})$ ions by the soil colloidal phase.

Co: In general, the $\mathrm{Co}^{2+}$ concentration shows higher values in arid and semiarid regions, whereas its concentrations in soils of glaciated regions are often low [65]. Cobalt concentrations showed negative significant correlations with both silt and clay and organic matter fractions $(\mathrm{r}=-0.60$ and -0.87 , respectively), which indicates the importance of these fractions in the stabilization of $\mathrm{Co}^{2+}$ ions [70]. Similarly, the soil $\mathrm{pH}$ value significantly correlated with $\mathrm{Co}^{2+}$ extractability due to the activation of chemisorption forces at high $\mathrm{pH}$ values of the soil [71]. Conversely, $\mathrm{Co}^{2+}$ extractability showed a strong positive correlation $(\mathrm{r}=0.94, p<0.01)$ with available $\mathrm{Ca}^{2+}$ due to the competition between $\mathrm{Ca}^{2+}$ and $\mathrm{Co}^{2+}$ ions onto the active sorption sites. Consequently, soluble calcium salts are often used as efficient $\mathrm{Co}^{2+}$ extractants in calcareous soils [72].

$\mathrm{Cu}$ : A notable highly significant correlation $(\mathrm{r}=0.83, p<0.01)$ was observed between extractable $\mathrm{Co}^{2+}$ and the EC value of the soil since the increment in the ionic strength of the soil solution might condensate the diffused double layer of the colloidal phase, which constrains the approaching $\mathrm{Cu}^{2+}$ ions to the active sorption sites [73]. In contrast, $\mathrm{pH}$ and $\mathrm{CaCO}_{3}$ showed negative significant correlations with $\mathrm{Cu}^{2+}$ ions $(\mathrm{r}=-0.58$ and -0.66 , respectively). The binding capacity of $\mathrm{Cu}^{2+}$ ions onto the colloidal soil components might increase significantly with the increasing $\mathrm{pH}$ value of the soil due to hydroxylation of 
$\mathrm{pH}$-dependent charges and the increasing electronegativity of the soil [73]. Furthermore, the formation of hydroxyl and carbonate complexes at high $\mathrm{pH}$ and $\mathrm{CaCO}_{3}$ values might inhibit the extractability of $\mathrm{Cu}^{2+}$ ions [65]. Meanwhile, the positive significant correlations with $\mathrm{Ca}^{2+}, \mathrm{Mg}^{2+}$, and $\mathrm{Na}^{+}$ions might be attributed to the competition between $\mathrm{Cu}^{2+}$ and those metal ions onto the available sorption sites.

$F e$ : Unlike most reported studies, a positive significant correlation was obtained between soil $\mathrm{pH}$ and extractable $\mathrm{Fe}^{2+}(\mathrm{r}=0.60, p<0.05)$. In our study, the coastal locations were marked with higher $\mathrm{pH}$ values. The higher $\mathrm{Fe}^{2+}$ extractability in these locations could be attributed to the reduction of $\mathrm{Fe}^{3+}$ to $\mathrm{Fe}^{2+}$ and the dissolution of iron carbonate complexes upon waterlogging by tidal entry. The negative significant correlation $(\mathrm{r}=-0.78$, $p<0.01$ ) between $\mathrm{Fe}^{2+}$ extractability and available $\mathrm{K}^{+}$ions is linked to their competition onto sorption sites.

$\mathrm{Hg}$ : The negative significant correlations between extractable $\mathrm{Hg}^{2+}$ ions and silt and clay $(-0.84, p<0.01)$ and organic matter $(-0.94, p<0.01)$ fractions are interlinked with the tendency of these components to form insoluble fractions with $\mathrm{Hg}^{2+}$ ions [65]. The soil reaction $(\mathrm{pH})$ also showed a negative significant correlation with extractable $\mathrm{Hg}^{2+}$ ions $(\mathrm{r}=-0.81, p<0.01)$ as the $\mathrm{Hg}^{2+}$ flux from the soil matrix at alkaline soil conditions is often low [72]. Calcium carbonate and DTPA-extractable $\mathrm{Ca}^{2+}$, however, showed positive correlations with $\mathrm{Hg}^{2+}$ ions ( 0.51 and 0.86 , respectively). It is widely accepted that $\mathrm{CaCO}_{3}$ and active $\mathrm{Ca}^{2+}$ ions can increase the aggregation/stability of soil organic matter, thereby reducing its capacity toward the chemisorption of $\mathrm{Hg}^{2+}$ ions [74].

$M n$ : The extractable $\mathrm{Mn}^{2+}$ ions were positively correlated with the silt and clay fraction $(0.56, p<0.05)$, extractable $\mathrm{Ca}^{2+}(0.82, p<0.01)$, and soluble $\mathrm{HCO}_{3}{ }^{-}$ions $(0.77$, $p<0.01)$. Negative correlations, however, were observed with organic matter $(-0.60$, $p<0.05)$ and $\mathrm{pH}(-0.93, p<0.01)$. Manganese oxides (e.g., vernadite and birnessite) are typical constitutions of clay minerals [75]. $\mathrm{Mn}^{2+}$ ions also showed a high affinity toward precipitation as bicarbonate and organic manganese complexes. Those are governed by multiple soil reactions, of which soil $\mathrm{pH}$ and redox reactions are the most important [65]. The positive correlation between $\mathrm{Mn}^{2+}$ and $\mathrm{Ca}^{2+}$ ions is mainly related to the ion exchange mechanism, which increased the desorbability of $\mathrm{Mn}^{2+}$ ions.

$\mathrm{Ni}$ : A negative significant correlation $(\mathrm{r}=0.63, p<0.05)$ was observed between $\mathrm{Mn}^{2+}$ ions and the silt and clay fraction given their high binding forces by clay minerals (montmorillonite, in particular) [76]. Extractable $\mathrm{Ni}^{2+}$ ions also showed a positive correlation with $\mathrm{CaCO}_{3}(0.73, p<0.01)$; however, it showed a negative correlation with $\mathrm{K}^{+}$ions $(-0.89$, $p<0.01$ ). Nickel is slightly mobile in soil and exists mainly in immobile forms [65]. Meanwhile, the sorbed $\mathrm{Ni}^{2+}$ ions onto the nanoscale calcium carbonate fraction might exchange with $\mathrm{K}^{+}$ions onto the active sorption sites.

$\mathrm{Pb}$ : The positive significant correlation between $\mathrm{Pb}^{2+}$ ions and the silt and clay fraction agrees with that obtained by [65], who reported that $\mathrm{Pb}$ mineral distribution in soil shows a correlated trend of values with the fine granulometric fraction. In arid and semiarid conditions, $\mathrm{Pb}$ sulfides are oxidized slowly and show a high tendency toward forming immobile carbonate fractions with less extractability potentials [77]. This might be the reason for the negative significant correlations with $\mathrm{CaCO}_{3}$ and $\mathrm{HCO}_{3}{ }^{-}$ions $(-0.62$ and -0.56 , respectively, $p<0.05$ ). Positive significant correlations were further noticed with $\mathrm{Mg}^{2+}(0.62, p<0.05), \mathrm{K}^{+}(0.95, p<0.01)$, and $\mathrm{Na}^{+}(0.54, p<0.05)$, probably due to their easy exchange with $\mathrm{Pb}^{2+}$ ions onto the active sorption sites of the colloidal phase [78]. The positive significant correlation between available $\mathrm{Pb}^{2+}$ and $\mathrm{Cl}^{-}$ions $(0.56, p<0.05)$ is mainly related to the positive effect of $\mathrm{Cl}^{-}$ions on increasing the extractability potentials of $\mathrm{Pb}^{2+}$ ions from active soil fractions.

$\mathrm{Zn}$ : Unlike most other PTEs, Zn appeared to exist in more soluble forms with high leachability potentials; however, high $\mathrm{HCO}_{3}{ }^{-}$values precipitated $\mathrm{Zn}$ species into $\mathrm{Zn}\left(\mathrm{HCO}_{3}\right)_{2}$ with a lower degree of leachability [79]. This could be the reason for the positive significant correlation with $\mathrm{HCO}_{3}{ }^{-}(0.75, p<0.01)$. A negative significant correlation was observed between $\mathrm{Zn}^{2+}$ ions and the $\mathrm{pH}$ value of the soil $(-0.94, p<0.01)$. The 
desorbability of $\mathrm{Zn}^{2+}$ ions decreased continuously with the increasing $\mathrm{pH}$ value of the soil, and the proportion of sorbed $\mathrm{Zn}^{2+}$ that could be extracted declined dramatically as the $\mathrm{pH}$ value increased above 6.5 [80]. On the contrary, the positive significant correlation with $\mathrm{Ca}^{2+}$ ions $(0.86, p<0.01)$ might be due to maximizing the desorbability of $\mathrm{Zn}^{2+}$ ions by the ion exchange mechanism.

\subsection{Ecological Risk Assessment of PTE Concentrations in Soil}

The calculated $\mathrm{I}_{\text {geo }}$ values showed an uncontaminated effect $\left(0<\mathrm{I}_{\text {geo }}<1\right)$ of most PTEs $(\mathrm{Cd}, \mathrm{Cu}, \mathrm{Fe}, \mathrm{Ni}, \mathrm{Pb}$, and $\mathrm{Zn})$. Other elements, however, varied in their contamination level among rhizospheric soils (Figure 2). The contamination level of $\mathrm{Cr}$ and $\mathrm{Co}$ was the highest among other PTEs and reached a highly contaminated degree in some rhizospheric soils $\left(3<\mathrm{I}_{\text {geo }}<4\right)$. The contamination level of $\mathrm{Hg}$ and $\mathrm{Mn}$ was slight in most cases, except for $\mathrm{L}_{3}$, which showed a moderate Mn contamination level $\left(2<\mathrm{I}_{\text {geo }}<3\right)$.
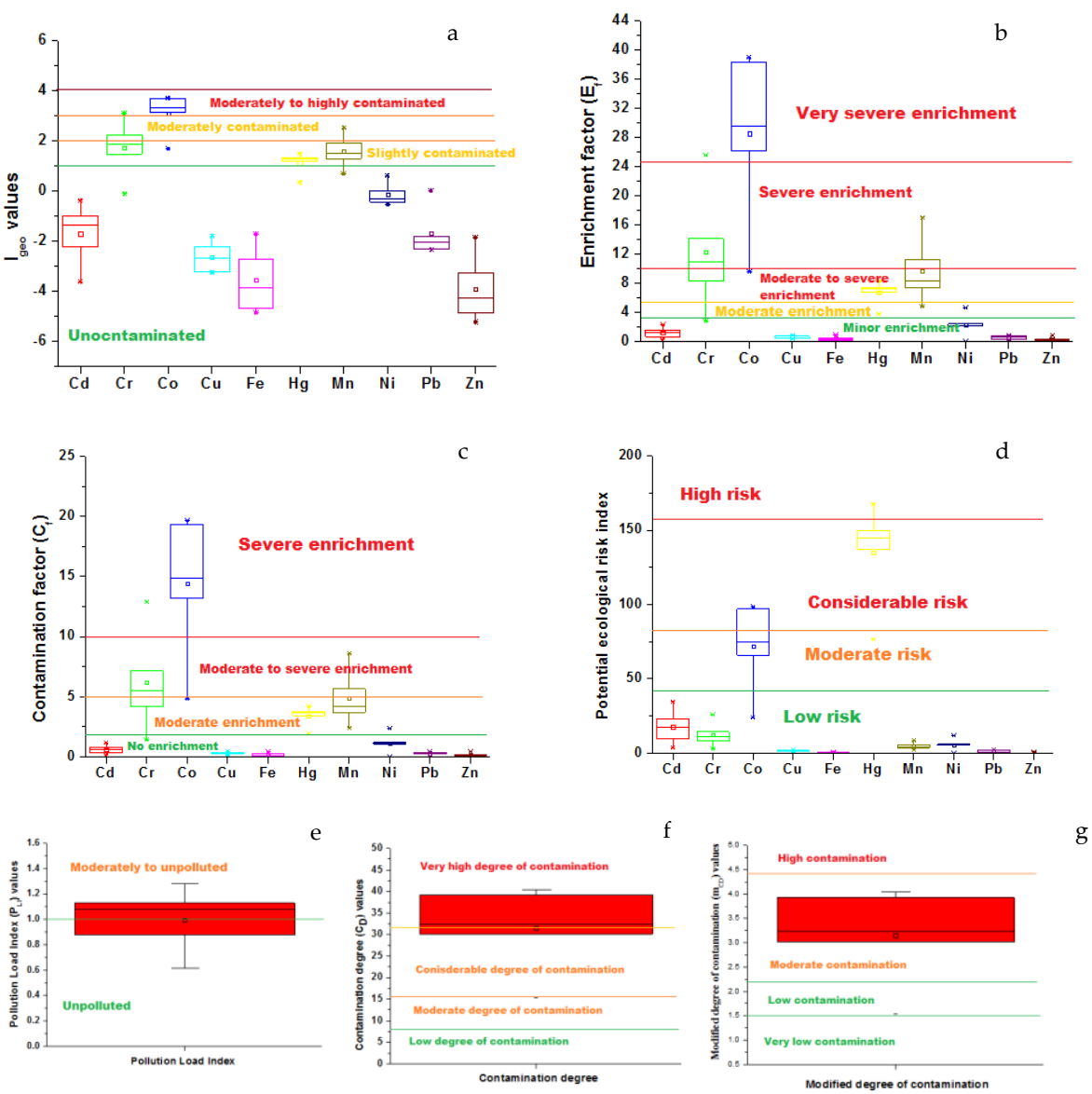

Figure 2. Ecological risk assessment of PTEs in soil: (a) geo-accumulation index ( $\left.\mathrm{I}_{\text {geo }}\right)$, (b) enrichment factor $\left(E_{f}\right),(\mathbf{c})$ contamination factor $\left(C_{F}\right),(d)$ potential ecological risk index $\left(E_{r}^{i}\right),(e)$ pollution load index $\left(\mathrm{P}_{\mathrm{LI}}\right)$, and $(\mathbf{f})$ contamination degree $\left(\mathrm{C}_{\mathrm{D}}\right)$ and modified degree of contamination $(\mathrm{mCD})$.

The data of the enrichment factor $\left(\mathrm{E}_{\mathrm{f}}\right)$ show no enrichment of the $\mathrm{Cu}, \mathrm{Fe}, \mathrm{Pb}$, and $\mathrm{Zn}$ elements $\left(0<\mathrm{E}_{\mathrm{f}}<1\right)$, minor enrichment of $\mathrm{Ni}$ in most rhizospheric soils, except for $\mathrm{L}_{1}$ (moderate enrichment), moderate to severe enrichment of $\mathrm{Hg}$ and $\mathrm{Mn}$ in most samples, except for $L_{2}$ and $L_{3}$ (severe enrichment), and very severe enrichment of $C o\left(25<E_{f}<50\right)$.

The data of the single contamination factor show no enrichment of most TEs; however, $\mathrm{Cr}$ and $\mathrm{Mn}$ reached the limit of moderate to severe enrichment, and Co reached the limit of severe enrichment. Likewise, the potential ecological risk index indicated a low risk of all TEs except $\mathrm{Co}$, which showed a considerable risk. The pollution load index values ranged between unpolluted to moderately polluted. The contamination degree pointed 
to a very high degree of contamination, although the modified degree of contamination showed only moderate contamination.

\subsection{PTE Concentrations in Plants}

The data presented in the box-and-whisker diagrams (Figure 3) show the median, maximum, and minimum concentrations of PTEs in the tested halophytes. The median concentrations of PTEs in plants $\left(\mathrm{mg} \mathrm{kg}^{-1}\right)$ were ranked as follows: $\mathrm{Fe}$ (1112), Zn (114.4), $\mathrm{Cu}$ (81.3), $\mathrm{Mn}$ (76.3), $\mathrm{Cr}$ (30.0), $\mathrm{Pb}$ (13.9), Ni (3.6), Co (3.2), Cd (2.8), and $\mathrm{Hg}$ (1.95). Z. coccineum leaves contained the highest levels ( $\mathrm{mg} \mathrm{kg}^{-1}$ ) of $\mathrm{Co}$ (26.4), $\mathrm{Cu}$ (121), $\mathrm{Fe}$ (2808), $\mathrm{Pb}(84.1)$, and $\mathrm{Zn}$ (138.2). H. perfoliata, however, showed the highest concentrations $\left(\mathrm{mg} \mathrm{kg}^{-1}\right)$ of $\mathrm{Cd}(6.4)$ and $\mathrm{Hg}$ (8.1). Meanwhile, T. nilotica recorded the highest concentration $\left(\mathrm{mg} \mathrm{kg}^{-1}\right)$ of $\mathrm{Cr}$ (38.06) and Mn (92.9). On the other hand, H. crispum showed relatively lower PTE concentrations in general and recorded the minimum values $\left(\mathrm{mg} \mathrm{kg}^{-1}\right)$ of $\mathrm{Cr}$ (7.7), Co (N.D.), $\mathrm{Hg}$ (ND), and $\mathrm{Zn}$ (98.6). Meanwhile, A. marina attained high values of $\mathrm{Hg}$ (2.7) and $\mathrm{Mn}$ (84.5). The recorded concentrations of most PTEs exceed the permissible limits $\left(\mu \mathrm{g} \mathrm{g}^{-1}\right)$ that have been justified by standard regulatory bodies (e.g., the WHO, FAO): $\mathrm{Cd}(0.1)$, $\mathrm{Cu}$ (73), $\mathrm{Fe}$ (425), Mn (500), Ni (67), and Zn (100) [81], suggesting their potential use for phytoremediation purposes and medical applications $[82,83]$ rather than other uses involving human consumption.
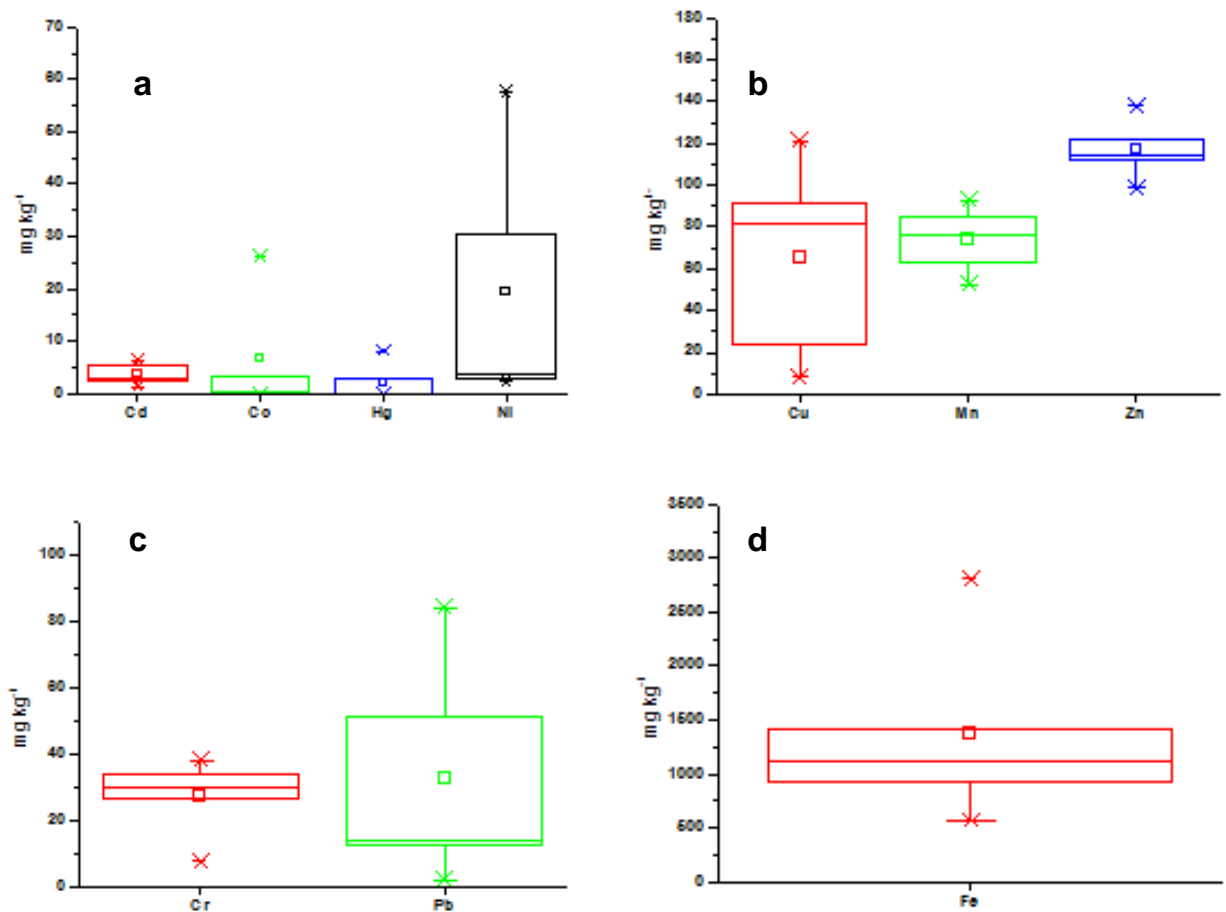

Figure 3. Total concentrations of PTEs $\left(\mathrm{mg} \mathrm{kg}^{-1}\right)$ in halophytes. The box chart is symbolized by the median (center line), mean (dot), lower and upper quartiles (the lower and upper borders of the box, respectively), and whiskers-error bars (the minimum and maximum values): (a) cadmium, coobalt, mercury and nickel (b) copper, manganese, and zinc, (c) chromium and lead, (d) iron.

The soil-to-plant transfer factors including the bio-concentration ratio $(\mathrm{BCR}=\mathrm{PTE}$ concentrations in plants/available PTE concentrations in soils) [84] can interpret the hyperaccumulating potentials of PTEs by wild plants, thereby indicating the usability of these plants for phytoremediation techniques (plants having BCR $>1$ are considered as hyperaccumulators). The tested halophytes showed hyperaccumulating potentials for all studied PTEs with BCR values $>1$ (Table 4 ). 
Table 4. Bioaccumulation Factor (BAF) of PTEs in Endemic Wild Plants.

\begin{tabular}{cccccc}
\hline PTEs & TN & HC & ZC & HP & AM \\
\hline $\mathrm{Cd}$ & $120.31 \pm 1.95$ & $80.15 \pm 0.28$ & $128.10 \pm 1.79$ & $92.72 \pm 0.82$ & $189.47 \pm 4.88$ \\
$\mathrm{Cr}$ & $26.80 \pm 0.24$ & $12.69 \pm 0.10$ & $38.33 \pm 0.24$ & $219.02 \pm 6.07$ & $57.27 \pm 0.45$ \\
$\mathrm{Co}$ & $1.12 \pm 0.01$ & $\mathrm{~N} . \mathrm{D}$. & $45.35 \pm 0.08$ & $5.45 \pm 0.08$ & $22.63 \pm 0.22$ \\
$\mathrm{Cu}$ & $64.97 \pm 13.26$ & $43.41 \pm 6.50$ & $40.85 \pm 21.44$ & $2.22 \pm 0.57$ & $11.91 \pm 3.74$ \\
$\mathrm{Fe}$ & $29.15 \pm 2.84$ & $198.28 \pm 20.15$ & $443.85 \pm 42.55$ & $82.83 \pm 7.33$ & $22.95 \pm 1.88$ \\
$\mathrm{Hg}$ & $\mathrm{N} . \mathrm{D}$. & $\mathrm{N} . \mathrm{D}$. & $1.74 \pm 0.15$ & $7.33 \pm 1.64$ & $2.42 \pm 0.59$ \\
$\mathrm{Mn}$ & $5.33 \pm 0.47$ & $2.35 \pm 0.23$ & $1.87 \pm 0.17$ & $2.66 \pm 0.23$ & $7.42 \pm 0.63$ \\
$\mathrm{Ni}$ & $3.57 \pm 1.02$ & $184.88 \pm 42.40$ & $72.53 \pm 34.55$ & $9.84 \pm 0.96$ & $8.20 \pm 0.87$ \\
$\mathrm{~Pb}$ & $44.41 \pm 4.37$ & $3.27 \pm 0.76$ & $37.50 \pm 3.56$ & $0.50 \pm 0.08$ & $4.19 \pm 1.91$ \\
$\mathrm{Zn}$ & $116.53 \pm 11.68$ & $61.04 \pm 6.46$ & $16.30 \pm 1.45$ & $35.30 \pm 3.56$ & $137.31 \pm 13.13$ \\
\hline
\end{tabular}

\subsection{Halophyte Physiological Analysis}

Our chemical analysis of rhizospheric soils in the tested salt marshes revealed that their inhabiting species suffer from varying levels of salinity (Table 1), nutrient deficiency (N, P, several micronutrients; Table 2), and elevated levels of PTEs (Figure 1). These results agree with the general belief that halophytes in their natural habitats suffer from various types of stress [15]. Such multiple stresses induce both secondary water stress and oxidative damage to cellular structures. However, the tested halophytes did not show any obvious symptoms of toxicity, suggesting that such multiple stress-induced signals might trigger cross-talk among various physiological pathways that end with activation of "cross-tolerance" allowing the tested species to respond effectively to single or multiple stresses [15]. Consistent with that, salinity improved the growth of halophytes such as Sesuvium portulacastrum, Spartina densiflora, and Mesembryanthemum crystallinum under PTE stress such as $\mathrm{Cd}$ and $\mathrm{Zn}$. Such an enhancing effect is attributed to the possible role of $\mathrm{Na}^{+}$ in osmotic adjustment and induction of synthesis of proline, polyamines, and glutathione as well as a reduction in ethylene and abscisic acid $[85,86]$. The output of such a cross-talk, the possible species-specific anatomical structures, and the extent of the internal cellular tolerance to each of such multiple stresses stand behind the differential physiological responses and adaptability of the tested halophytes and make each halophyte behave as a unique biological system.

The consequences of salinity, nutrient, and PTE stresses in the soils of the current study areas on the oxidant and antioxidant systems in the dominating halophytes were monitored (Figure 4). Our measurements of oxidative stress biomarkers revealed much lower levels of MDA in the leaves of T. nilotica, H. crispum, and Halopeplus perfoliata (Figure 4a), and such a response was associated with relatively low levels of $\mathrm{H}_{2} \mathrm{O}_{2}$ (Figure 4 b). These results indicate a reduced extent of oxidative stress in these species. In T. nilotica and $H$. crispum, the reduced levels of MDA can be ascribed mainly to (i) the low salinity in their rhizospheric soils (3.74 dS m $\mathrm{m}^{-1}, 2.46 \mathrm{dS} \mathrm{m}^{-1}$, Table 1), and (ii) their relatively higher antioxidant compounds such as total flavonoids (Figure 4c), phenolics (Figure 4d), and carotenoids (Figure 5d). These compounds can contribute significantly to the overall antioxidant potential and thus reduce ROS and, consequently, MDA. Consistent with this, significant content of phenolics and high antioxidant activity have also been confirmed in Tamarix gallica [87]. (iii) The salt glands and trichomes in T. nilotica as well as the succulence in $H$. crispum may reduce the PTE-induced ROS formation. The above reasons thus synergistically reduce ROS and, consequently, MDA. The reduced oxidative stress in $H$. perfoliata, regardless of the high EC values and PTE content in its rhizospheric soil, suggests that this halophyte has optimized its antioxidant defense to minimize the oxidative damage it encounters in its natural environment. In support of this hypothesis, [18] reported high catalase activity in $\mathrm{H}$. perfoliata at $150 \mathrm{mM} \mathrm{NaCl}$; this approximately matches the level of total soluble salts in the rhizopheric soil of H. perfoliata in the current study [18]. They also reported a salinity-induced reduction in the activities of both SOD and APX with minimal effect on GR, suggesting that active superoxide $\left(\mathrm{O}_{2}\right)$ radicals are not synthesized 
in response to salinity stress in $H$. perfoliata [18]. Further, its succulence may also minimize the detrimental effects of both salinity and PTEs.
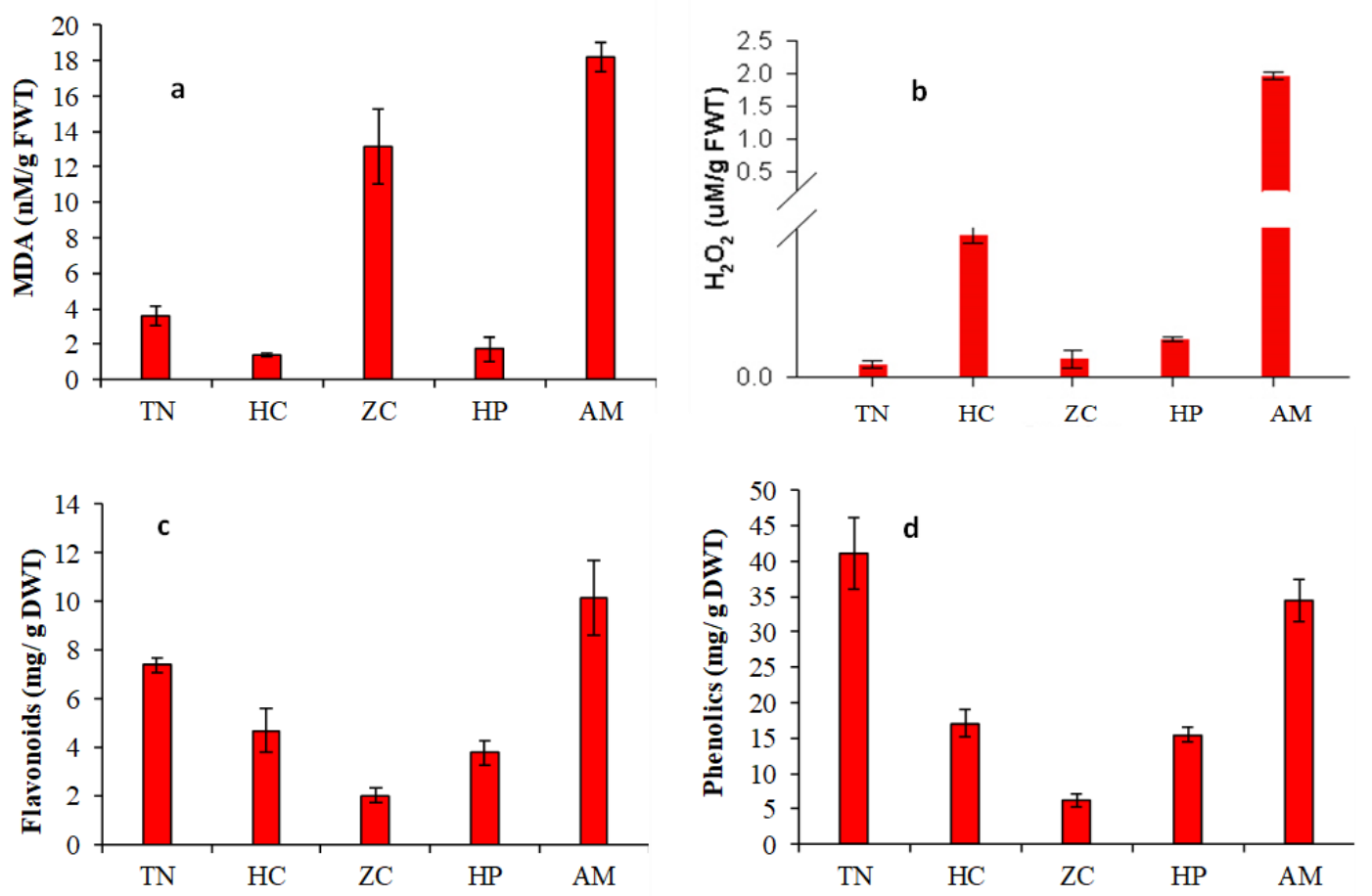

Figure 4. Oxidative stress and antioxidant indicators: (a) lipid peroxidation (malondialdehyde; MDA), (b) leaf hydrogen peroxide $\left(\mathrm{H}_{2} \mathrm{O}_{2}\right)$, (c) total flavonoids, and (d) total phenolics. Shown are the mean values of three biological replicates \pm standard deviations. On the abscissa axis, the initials of the tested species are reported.

Unlike the above-mentioned species (T. nilotica, H. crispum, and H. perfoliata), both A. marina and Z. coccineum had much higher MDA levels in their leaves (Figure 4a), and such a response was associated with the higher $\mathrm{H}_{2} \mathrm{O}_{2}$ level in A. marina only (Figure $4 b$ ). These results indicate a disturbance of the equilibrium between the oxidative and antioxidative capacities at the cellular level in A. marina and Z. coccineum [21,88]. High MDA levels in $A$. marina and $Z$. coccineum leaves may be ascribed, in part, to the high salinity in their rhizospheric soils (9.92 $\mathrm{dS} \mathrm{m}^{-1}$ and $9.94 \mathrm{dS} \mathrm{m}^{-1}$, Table 1), and the simultaneous toxicity of PTEs in their leaves, particularly $\mathrm{Hg}, \mathrm{Co}$, and $\mathrm{Mn}$ in A. marina, and $\mathrm{Co}, \mathrm{Cu}, \mathrm{Fe}, \mathrm{Zn}$, and $\mathrm{Ni}$ in Z. coccineum compared to T. nilotica and H. crispum. High salinity levels impair electron transport in chloroplasts and mitochondria and lead to the formation of ROS which, in turn, leads to MDA accumulation $[89,90]$. On the other hand, the higher level of $\mathrm{H}_{2} \mathrm{O}_{2}$ in A. marina in the presence of transient PTEs can be a major source of highly reactive hydroxyl radicals, of which cells do not have an enzymatic system to detoxify, and thus they induce high MDA levels in A. marina leaves [27]. Further, the level of $\mathrm{Hg}$ in A. marina leaves exceeded the toxic threshold of $\mathrm{Hg}$ in plants [91], thereby interfering with mitochondrial activity and triggering ROS generation and MDA accumulation [92]. Mercury $(\mathrm{Hg})$ can also bind to water channel proteins, inducing stomatal closure and thus hindering water flow in A. marina [93]. Interestingly, despite the high foliar levels of $\mathrm{H}_{2} \mathrm{O}_{2}$ and MDA in A. marina leaves, they exhibited growth vigor and efficient $C$ assimilation as indicated by their high TSS and sucrose levels (see below). These results suggest that chloroplasts in A. marina seem to be protected against ROS damage, which indicates that $A$. marina has developed adaptive mechanisms that could facilitate the persistence of elevated cellular $\mathrm{H}_{2} \mathrm{O}_{2}$ as a stress signal [27], as it has been described in the Eutrema salsugineum halophyte [94-96]. Interestingly, in Z. coccineum leaves, high MDA levels (Figure 4a) were associated with the highest levels of total PTEs among the tested halophytes. Yet, they contained relatively lower levels of $\mathrm{H}_{2} \mathrm{O}_{2}$, suggesting the involvement of ROS other than 
$\mathrm{H}_{2} \mathrm{O}_{2}$ in lipid peroxidation. Toxic levels of PTEs can indirectly deplete low-molecular weight antioxidants [9]. Consistent with that, Z. coccineum leaves had the lowest level of total flavonoids (Figure 5a) and total phenolics (Figure 5b) among the tested species. Toxic levels of the tested PTEs might also have suppressive effects on the activities of some antioxidant enzymes [21,97]. Altogether, these heavy metal-induced responses trigger ROS generation [9], which, in turn, induces high MDA accumulation and lipid peroxidation in Z. coccineum.
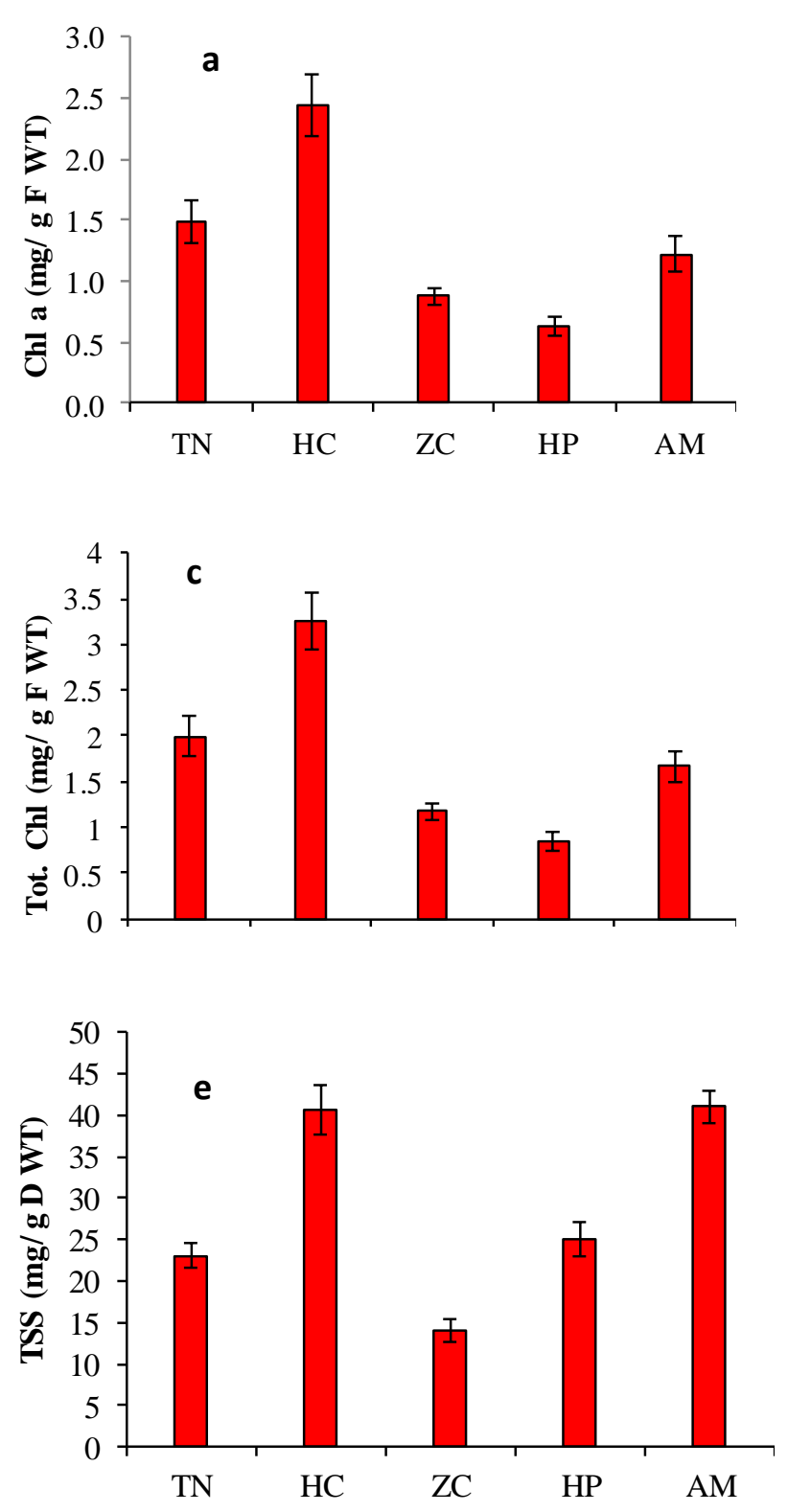
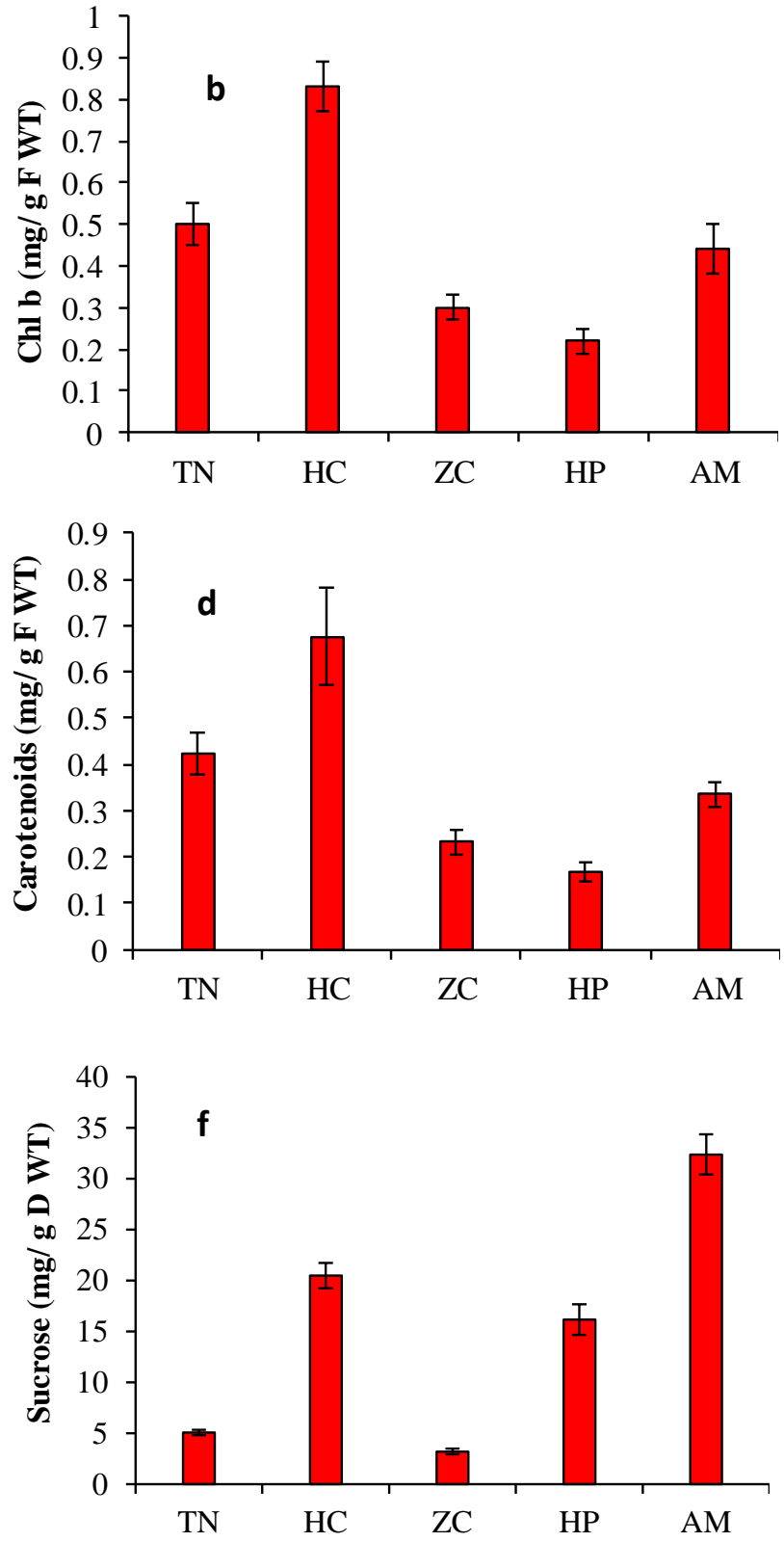

Figure 5. Leaf photosynthetic pigments and C assimilation: (a) chlorophyll a (Chl a), (b) chlorophyll b (Chl b), (c) total chlorophyll (Tot. Chl), (d) carotenoids (Cars), (e) total soluble sugars (TSS), and sucrose (f). Shown are the mean values of three biological replicates \pm standard deviations. On the abscissa axis, the initials of the tested species are reported.

The impact of the above differential oxidative stress on $\mathrm{C}$ metabolism in the tested species was also monitored. H. crispum, T. nilotica, and A. marina had significantly higher chl $\mathrm{a}$, chl b, and total chl than Z. coccineum and H. perfoliata (Figure 5). Such a high chlorophyll content was associated with both the high carotenoid (Figure 5d) and total leaf N (Figure 6) levels, which are crucial for both chlorophyll synthesis and activity. The relatively high carotenoid levels protect photosynthetic pigments via quenching ${ }^{1} \mathrm{O}_{2}$ and peroxyl radicals 
that are generated during excess excitation of chlorophyll as a result of intensive light and high temperatures $[34,98]$. In addition, the importance of adequate leaf $\mathrm{N}$ for chlorophyll synthesis is well documented. Altogether, the two factors improve $C$ assimilation and thus explain the higher foliar TSS and sucrose in H. crispum and A. marina (Figure 5e,f). In T. nilotica, the higher chlorophyll and carotenoid levels were not translated into high TSS and sucrose, and such a response can be ascribed to its high foliar levels of PTEs, particularly $\mathrm{Cd}$, which inhibits the leaf photosynthetic rate and intracellular $\mathrm{CO}_{2}$ concentration of plants and consequently reduces carbohydrate synthesis [92,99]. In $H$. perfoliata and Z. coccineum, the high salinity in their rhizospheric soil (Table 1) reduced photosynthesis and overall $\mathrm{CO}_{2}$ assimilation via a reduction in the chlorophyll content (Figure 6), decreasing mesophyll $\mathrm{CO}_{2}$ availability as a result of stomatal closure to minimize water loss [100-102] and inhibiting Rubisco activity [103]. In addition, high salinity often leads to an overreduction in the photosynthetic electron transport chain, resulting in a higher demand for alternative energy sinks to prevent photoinhibition of photosystem II (PSII) [104].

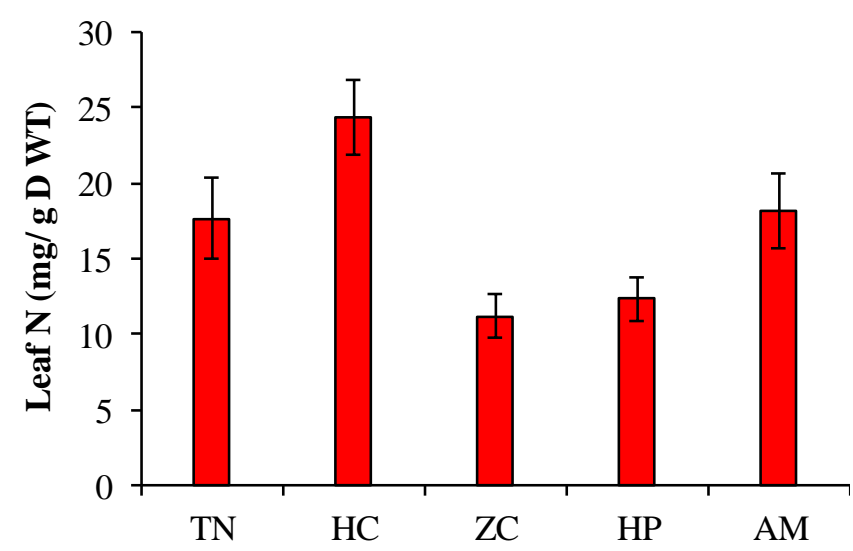

Figure 6. Leaf $\mathrm{N}$ content. Shown are the mean values of three biological replicates \pm standard deviations. On the abscissa axis, the initials of the tested species are reported.

\section{Conclusions}

The soils of the tested regions are under high risk of contamination with various PTEs as a result of active oil trading and modernization activities. In addition, the successful growth and adaptation of the tested halophytes in the tested salt marshes regardless of their higher salinity and PTE contents indicates that these plants successfully maintain a viable physiological status of their cells under multiple stresses in such harsh environments. In addition, the leaves of the tested halophytes showed differential intercellular tolerance against high levels of most of the tested PTEs which were considerably above their toxic levels. A. marina accumulated exceptionally high $\mathrm{Cd}, \mathrm{Zn}$, and $\mathrm{Mn}$ along with higher levels of $\mathrm{Cr}, \mathrm{Co}$, and $\mathrm{Hg}$, whereas $\mathrm{H}$. perfoliata accumulated the highest levels of $\mathrm{Cr}$ and $\mathrm{Hg}$. On the other hand, the leaves of $Z$. coccineum accumulated high levels of $\mathrm{Co}, \mathrm{Fe}$, and $\mathrm{Pb}$, while T. nilotica had higher levels of $\mathrm{Cu}, \mathrm{Pb}, \mathrm{Cd}$, and $\mathrm{Zn}$. H. crispum leaves accumulated the highest $\mathrm{Ni}$ levels among the tested halophytes. These results suggest that the tested halophytes may have high PTE accumulation potentials at the whole plant level since the bio-concentration factors of metals such as $\mathrm{Cu}, \mathrm{Zn}, \mathrm{Cd}, \mathrm{Cr}$, and $\mathrm{Hg}$ are usually higher in roots than in leaves [105]. In addition, these results, along with the high biomass of the tested halophytes, highlight their capabilities as phytoextractors of their corresponding PTEs and their high potential as efficient, cost-effective tools for phytoremediation of salt- and PTE-affected lands. However, the increased levels of PTEs in the leaves of the tested halophytes, compared to their permissible levels in vegetables, might limit their uses related to direct human consumption.

Supplementary Materials: The following are available online at https:/ /www.mdpi.com/article/10 .3390/su132011282/s1, Table S1: Ecological Risk Assessment Parameters and Their Contamination 
Levels, Table S2: Median Values of PTE Concentrations $\left(\mathrm{mg} \mathrm{kg}^{-1}\right)$ in Soil (S) and Halophyte (h) Samples in the Current Study Compared to Former Reported Result.

Author Contributions: Conceptualization, F.I. and A.M.; software, N.A.-H.; validation, F.I. and A.M.; formal analysis, F.I. and A.M.; resources, F.I.; data curation, F.I. and M.E.-M.; writing-original draft preparation, N.A.-H. and M.E.-M.; writing—review and editing, F.I. and A.M.; visualization, N.A.-H. and M.E.-M.; supervision, F.I.; project administration, F.I. and N.A.-H.; funding acquisition, F.I. and N.A.-H. All authors have read and agreed to the published version of the manuscript.

Funding: The authors would like to thank the Deanship of Scientific Research at Umm Al-Qura University for supporting this work by Grant Code: 17-SCI-1-03- 0005.

Acknowledgments: The research team would like to thank Mohamed Al-Helasi for his help during samples collection and processing.

Conflicts of Interest: The authors declare no conflict of interest.

\section{References}

1. Sarika, M.; Zikos, A. Coastal Salt Marshes: Structure and Function of Plant Communities. In Handbook of Halophytes: From Molecules to Ecosystems towards Biosaline Agriculture; Grigore, M.-N., Ed.; Springer Nature: Cham, Switzerland, 2021 ; pp. 199-237.

2. Chen, L.; Gao, J.; Zhu, Q.; Wang, Y.; Yang, Y. Accumulation and Output of Heavy Metals by the Invasive Plant Spartina alterniflora in a Coastal Salt Marsh. Pedosphere 2018, 28, 884-894. [CrossRef]

3. Rajaram, R.; Ganeshkumar, A.; Muralisankar, T.; Sivaperumal, P. Bioaccumulation of metals in mangroves and salt marshes collected from Tuticorin coast of Gulf of Mannar marine biosphere reserve, Southeastern India. Mar. Pollut. Bull. 2020, 160, 111599. [CrossRef]

4. Vane, C.H.; Kim, A.W.; Moss-Hayes, V.; Turner, G.; Mills, K.; Chenery, S.; Barlow, T.S.; Kemp, A.C.; Engelhart, S.E.; Hill, T.D.; et al. Organic pollutants, heavy metals and toxicity in oil spill impacted salt marsh sediment cores, Staten Island, New York City, USA. Mar. Pollut. Bull. 2020, 151, 110721. [CrossRef]

5. Zhao, Q.; Bai, J.; Gao, Y.; Zhang, G.; Lu, Q.; Jia, J. Heavy metal contamination in soils from freshwater wetlands to salt marshes in the Yellow River Estuary, China. Sci. Total. Environ. 2021, 774, 145072. [CrossRef]

6. Alharbi, O.M.; Khattab, R.A.; Ali, I.; Binnaser, Y.S.; Aqeel, A. Assessment of heavy metals contamination in the sediments and mangroves (Avicennia marina) at Yanbu coast, Red Sea, Saudi Arabia. Mar. Pollut. Bull. 2019, 149, 110669. [CrossRef]

7. El-Sorogy, A.S.; Youssef, M.; Al-Kahtany, K. Evaluation of coastal sediments for heavy metal contamination, Yanbu area, Red Sea coast, Saudi Arabia. Mar. Pollut. Bull. 2021, 163, 111966. [CrossRef]

8. Shaltout, K.H.; Ahmed, M.T.; Alrumman, S.A.; Ahmed, D.A.; Eid, E.M. Evaluation of the carbon sequestration capacity of arid mangroves along nutrient availability and salinity gradients along the Red Sea coastline of Saudi Arabia. Oceanologia 2019, 62, 56-69. [CrossRef]

9. Ackova, D.G. Heavy metals and their general toxicity for plants. Plant Sci. Today 2018, 5, 14-18. [CrossRef]

10. Paithankar, J.G.; Saini, S.; Dwivedi, S.; Sharma, A.; Chowdhuri, D.K. Heavy metal associated health hazards: An interplay of oxidative stress and signal transduction. Chemosphere 2021, 262, 128350. [CrossRef]

11. Arif, Y.; Singh, P.; Siddiqui, H.; Bajguz, A.; Hayat, S. Salinity induced physiological and biochemical changes in plants: An omic approach towards salt stress tolerance. Plant Physiol. Biochem. 2020, 156, 64-77. [CrossRef]

12. Nikalje, G.C.; Bhaskar, S.D.; Yadav, K.; Penna, S. Halophytes: Prospective plants for future. In Ecophysiology, Abiotic Stress Responses and Utilization of Halophytes; Springer Nature: Singapore, 2019; pp. 221-234.

13. Sharma, S.S.; Dietz, K.-J. The relationship between metal toxicity and cellular redox imbalance. Trends Plant Sci. 2009, 14, 43-50. [CrossRef]

14. Nikalje, G.; Nikam, T.D.; Suprasanna, P. Looking at halophytic adaptation to high salinity through genomics landscape. Curr. Genom. 2017, 18, 542-552. [CrossRef]

15. Ben Hamed, K.; Ellouzi, H.; Talbi, O.Z.; Hessini, K.; Slama, I.; Ghnaya, T.; Munné-Bosch, S.; Savouré, A.; Abdelly, C. Physiological response of halophytes to multiple stresses. Funct. Plant Biol. 2013, 40, 883-896. [CrossRef]

16. Nikalje, G.C.; Suprasanna, P. Coping with metal toxicity-Cues from halophytes. Front. Plant Sci. 2018, 9, 777. [CrossRef]

17. Matinzadeh, Z.; Akhani, H.; Abedi, M.; Palacio, S. The elemental composition of halophytes correlates with key morphological adaptations and taxonomic groups. Plant Physiol. Biochem. 2019, 141, 259-278. [CrossRef]

18. Rasool, S.G.; Gulzar, S.; Hameed, A.; Edwards, G.E.; Khan, M.A.; Gul, B. Maintenance of photosynthesis and the antioxidant defence systems have key roles for survival of Halopeplis perfoliata (Amaranthaceae) in a saline environment. Plant Biol. 2019, 21, 1167-1175. [CrossRef]

19. Dassanayake, M.; Larkin, J.C. Making plants break a sweat: The structure, function, and evolution of plant salt glands. Front. Plant Sci. 2017, 8, 406. [CrossRef]

20. Lefèvre, I.; Marchal, G.; Ghanem, M.E.; Correal, E.; Lutts, S. Cadmium has contrasting effects on polyethylene glycol-Sensitive and resistant cell lines in the Mediterranean halophyte species Atriplex halimus L. J. Plant Physiol. 2010, 167, 365-374. [CrossRef] 
21. Bhaduri, A.M.; Fulekar, M.H. Antioxidant enzyme responses of plants to heavy metal stress. Rev. Environ. Sci. Bio Technol. 2012, 11, 55-69. [CrossRef]

22. Jithesh, M.N.; Prashanth, S.R.; Sivaprakash, K.R.; Parida, A.K. Antioxidative response mechanisms in halophytes: Their role in stress defence. J. Genet. 2006, 85, 237-254. [CrossRef]

23. Keunen, E.; Remans, T.; Bohler, S.; Vangronsveld, J.; Cuypers, A. Metal-Induced Oxidative Stress and Plant Mitochondria. Int. J. Mol. Sci. 2011, 12, 6894-6918. [CrossRef]

24. Mittler, R.; Vanderauwera, S.; Gollery, M.; Van Breusegem, F. Reactive oxygen gene network of plants. Trends Plant Sci. 2004, 9 , 490-498. [CrossRef]

25. Bienert, G.; Møller, A.L.; Kristiansen, K.A.; Schulz, A.; Møller, I.M.; Schjoerring, J.K.; Jahn, T.P. Specific Aquaporins Facilitate the Diffusion of Hydrogen Peroxide across Membranes. J. Biol. Chem. 2007, 282, 1183-1192. [CrossRef]

26. Henzler, T.; Steudle, E. Transport and metabolic degradation of hydrogen peroxide in Chara corallina: Model calculations and measurements with the pressure probe suggest transport of $\mathrm{H}_{2} \mathrm{O}_{2}$ across water channels. J. Exp. Bot. 2000, 51, 2053-2066. [CrossRef]

27. Bose, J.; Rodrigo-Moreno, A.; Shabala, S. ROS homeostasis in halophytes in the context of salinity stress tolerance. J. Exp. Bot. 2014, 65, 1241-1257. [CrossRef] [PubMed]

28. Demidchik, V. Mechanisms of oxidative stress in plants: From classical chemistry to cell biology. Environ. Exp. Bot. 2015, 109, 212-228. [CrossRef]

29. Miller, G.A.D.; Suzuki, N.; Ciftci-Yilmaz, S.; Mittler, R.O.N. Reactive oxygen species homeostasis and signalling during drought and salinity stresses. Plant Cell Environ. 2010, 33, 453-467. [CrossRef] [PubMed]

30. Tsukagoshi, H.; Busch, W.; Benfey, P.N. Transcriptional Regulation of ROS Controls Transition from Proliferation to Differentiation in the Root. Cell 2010, 143, 606-616. [CrossRef] [PubMed]

31. Das, K.; Roychoudhury, A. Reactive oxygen species (ROS) and response of antioxidants as ROS-scavengers during environmental stress in plants. Front. Environ. Sci. 2014, 2. [CrossRef]

32. Suo, J.; Zhao, Q.; David, L.; Chen, S.; Dai, S. Salinity Response in Chloroplasts: Insights from Gene Characterization. Int. J. Mol. Sci. 2017, 18, 1011. [CrossRef]

33. Asada, K. Production and Scavenging of Reactive Oxygen Species in Chloroplasts and Their Functions. Plant Physiol. 2006, 141, 391-396. [CrossRef]

34. Pospíšil, P. Production of Reactive Oxygen Species by Photosystem II as a Response to Light and Temperature Stress. Front. Plant Sci. 2016, 7, 1950. [CrossRef]

35. MacFarlane, G.; Burchett, M. Photosynthetic Pigments and Peroxidase Activity as Indicators of Heavy Metal Stress in the Grey Mangrove, Avicennia marina (Forsk.) Vierh. Mar. Pollut. Bull. 2001, 42, 233-240. [CrossRef]

36. Mandaville, J.P. Flora of Eastern Saudi Arabia; Routledge: New York, NY, USA, 2013.

37. Chaudhary, S.A. Flora of the Kingdom of Saudi Arabia, Illustrated; Ministry of Agriculture \& Water, National Herbarium: Riyadh, Saudi Arabia, 1999.

38. Jackson, M.L. Soil Chemical Analysis: Advanced Course; UW-Madison Libraries Parallel Press: Madison, WI, USA, 2005.

39. Gee, G.W.; Or, D. 2.4 Particle-size analysis. In Methods of Soil Analysis: Part 4 Physical Methods, 5.4; Dane, J.H., Topp, C.G., Eds.; Soil science society of America: Madison, WI, USA, 2002; pp. 255-293.

40. Muller, G. Index of geoaccumulation in sediments of the Rhine River. GeoJournal 1969, 2, 108-118.

41. Shaheen, S.M.; Shams, M.S.; Khalifa, M.R.; El-Dali, M.A.; Rinklebe, J. Various soil amendments and environmental wastes affect the (im)mobilization and phytoavailability of potentially toxic elements in a sewage effluent irrigated sandy soil. Ecotoxicol. Environ. Saf. 2017, 142, 375-387. [CrossRef] [PubMed]

42. Chester, R.; Stoner, J.H. Pb in Particulates from the Lower Atmosphere of the Eastern Atlantic. Nature 1973, 245, 27-28. [CrossRef]

43. Shaheen, S.M.; Antoniadis, V.; Kwon, E.; Song, H.; Wang, S.-L.; Hseu, Z.-Y.; Rinklebe, J. Soil contamination by potentially toxic elements and the associated human health risk in geo- and anthropogenic contaminated soils: A case study from the temperate region (Germany) and the arid region (Egypt). Environ. Pollut. 2020, 262, 114312. [CrossRef] [PubMed]

44. Hakanson, L. An ecological risk index for aquatic pollution control. A sedimentological approach. Water Res. 1980, 14, 975-1001. [CrossRef]

45. Tomlinson, D.L.; Wilson, J.; Harris, C.R.; Jeffrey, D.W. Problems in the assessment of heavy-metal levels in estuaries and the formation of a pollution index. Helgol. Mar. Res. 1980, 33, 566-575. [CrossRef]

46. Ouyang, S.-Q.; Liu, Y.-F.; Liu, P.; Lei, G.; He, S.-J.; Ma, B.; Zhang, W.-K.; Zhang, J.-S.; Chen, S.-Y. Receptor-like kinase OsSIK1 improves drought and salt stress tolerance in rice (Oryza sativa) plants. Plant J. 2010, 62, 316-329. [CrossRef]

47. Zhishen, J.; Mengcheng, T.; Jianming, W. The determination of flavonoid contents in mulberry and their scavenging effects on superoxide radicals. Food Chem. 1999, 64, 555-559. [CrossRef]

48. Alonsoborbalan, A.; Zorro, L.; Guillen, D.; Barroso, C.G. Study of the polyphenol content of red and white grape varieties by liquid chromatography-mass spectrometry and its relationship to antioxidant power. J. Chromatogr. A 2003, 1012, 31-38. [CrossRef]

49. Lichtenthaler, H.K. Chlorophylls and carotenoids: Pigments of photosynthetic biomembranes. In Methods in Enzymology; Academic Press: San Diego, CA, USA, 1987; Volume 148, pp. 350-382. [CrossRef] 
50. Hansen, J.; Møller, I. Percolation of starch and soluble carbohydrates from plant tissue for quantitative determination with anthrone. Anal. Biochem. 1975, 68, 87-94. [CrossRef]

51. van Handel, E. Direct microdetermination of sucrose. Anal. Biochem. 1968, 22, 280-283. [CrossRef]

52. Soil Survey Staff. Keys to Soil Taxonomy; United States Department of Agriculture, Soil Conservation Service: Washington, DC, USA, 2010

53. Gebauer, R.L.E.; Tenhunen, J.D.; Reynolds, J.F. Soil aeration in relation to soil physical properties, nitrogen availability, and root characteristics within an arctic watershed. Plant Soil 1996, 178, 37-48. [CrossRef]

54. Osland, M.J.; Gabler, C.A.; Grace, J.B.; Day, R.H.; McCoy, M.L.; McLeod, J.L.; From, A.S.; Enwright, N.M.; Feher, L.C.; Stagg, C.L.; et al. Climate and plant controls on soil organic matter in coastal wetlands. Glob. Chang. Biol. 2018, 24, 5361-5379. [CrossRef] [PubMed]

55. Mosa, A.; El-Ghamry, A.; Tolba, M. Functionalized biochar derived from heavy metal rich feedstock: Phosphate recovery and reusing the exhausted biochar as an enriched soil amendment. Chemosphere 2018, 198, 351-363. [CrossRef]

56. Mosa, A.; El-Ghamry, A.; Trüby, P.; Omar, M.; Gao, B.; Elnaggar, A.; Li, Y. Chemo-mechanical modification of cottonwood for Pb ${ }^{2+}$ removal from aqueous solutions: Sorption mechanisms and potential application as biofilter in drip-irrigation. Chemosphere 2016, 161, 1-9. [CrossRef]

57. Falcón, M.; González, C.; García, V.; Báez, J. The effect of chloride and bicarbonate levels in irrigation water on nutrition content, production and quality of cut roses 'Mercedes'. Sci. Hortic. 1986, 29, 373-385. [CrossRef]

58. Debez, A.; Saadaoui, D.; Slama, I.; Huchzermeyer, B.; Abdelly, C. Responses of Batis maritima plants challenged with up to two-fold seawater $\mathrm{NaCl}$ salinity. J. Plant Nutr. Soil Sci. 2010, 173, 291-299. [CrossRef]

59. Cottenie, A. Soil and Plant Testing as a Basis of Fertilizer Recommendations; FAO: Rome, Italy, 1980.

60. Ahmad, Z.; Mosa, A.; Zhan, L.; Gao, B. Biochar modulates mineral nitrogen dynamics in soil and terrestrial ecosystems: A critical review. Chemosphere 2021, 278, 130378. [CrossRef] [PubMed]

61. Mosa, A.; El-Ghamry, A.; Tolba, M. Biochar-supported natural zeolite composite for recovery and reuse of aqueous phosphate and humate: Batch sorption-desorption and bioassay investigations. Environ. Technol. Innov. 2020, 19, 100807. [CrossRef]

62. Yost, R.S.; Uchida, R. Interpreting soil nutrient analysis data. In Plant Nutrient Management in Hawaii Soils; Silva, J.A., Uchida, R.S., Eds.; University of Hawaii: Honolulu, HI, USA, 2000; pp. 87-94.

63. Touchette, B.W.; Burkholder, J.M. Review of nitrogen and phosphorus metabolism in seagrasses. J. Exp. Mar. Biol. Ecol. 2000, 250, 133-167. [CrossRef]

64. Sungur, A.; Soylak, M.; Ozcan, H. Investigation of heavy metal mobility and availability by the BCR sequential extraction procedure: Relationship between soil properties and heavy metals availability. Chem. Speciat. Bioavailab. 2014, 26, 219-230. [CrossRef]

65. Kabata-Pendias, A. Trace Elements in Soils and Plants; CRC Press: Boca Raton, FL, USA, 2010.

66. Zhang, Z.; Guo, G.; Zhao, H.; Wu, D. Partitioning, leachability, and speciation of chromium in the size-fractions of soil contaminated by chromate production. Chemosphere 2020, 263, 128308. [CrossRef]

67. Barnie, S.; Zhang, J.; Wang, H.; Yin, H.; Chen, H. The influence of $\mathrm{pH}$, co-existing ions, ionic strength, and temperature on the adsorption and reduction of hexavalent chromium by undissolved humic acid. Chemosphere 2018, 212, 209-218. [CrossRef]

68. Takahashi, Y.; Minai, Y.; Ambe, S.; Makide, Y.; Ambe, F.; Tominaga, T. Simultaneous determination of stability constants of humate complexes with various metal ions using multitracer technique. Sci. Total. Environ. 1997, 198, 61-71. [CrossRef]

69. Mangwandi, C.; Kurniawan, T.A.; Albadarin, A.B. Comparative biosorption of chromium (VI) using chemically modified date pits (CM-DP) and olive stone (CM-OS): Kinetics, isotherms and influence of co-existing ions. Chem. Eng. Res. Des. 2020, 156, 251-262. [CrossRef]

70. Woodward, G.L.; Peacock, C.L.; Otero-Fariña, A.; Thompson, O.R.; Brown, A.P.; Burke, I.T. A universal uptake mechanism for cobalt(II) on soil constituents: Ferrihydrite, kaolinite, humic acid, and organo-mineral composites. Geochim. Cosmochim. Acta 2018, 238, 270-291. [CrossRef]

71. Rawat, K.S.; Kumar, R.; Singh, S.K. Topographical distribution of cobalt in different agro-climatic zones of Jharkhand state, India. Geol. Ecol. Landscapes 2019, 3, 14-21. [CrossRef]

72. Jalali, M.; Majeri, M.; Najafi, S. Kinetic release and fractionation of cobalt in some calcareous soils. J. Geochem. Explor. 2019, 204, 131-141. [CrossRef]

73. Cao, J.; Lam, K.; Dawson, R.; Liu, W.; Tao, S. The effect of $\mathrm{pH}$, ion strength and reactant content on the complexation of $\mathrm{Cu}^{2+}$ by various natural organic ligands from water and soil in Hong Kong. Chemosphere 2004, 54, 507-514. [CrossRef]

74. Rowley, M.C.; Grand, S.; Verrecchia, P. Calcium-mediated stabilisation of soil organic carbon. Biogeochemistry 2018, 137, 27-49. [CrossRef]

75. Quintanilla-Villanueva, G.; Villanueva-Rodríguez, M.; Guzmán-Mar, J.; Torres-Gaytan, D.; Hernández-Ramírez, A.; OrozcoRivera, G.; Hinojosa-Reyes, L. Mobility and speciation of mercury in soils from a mining zone in Villa Hidalgo, SLP, Mexico: A preliminary risk assessment. Appl. Geochem. 2020, 122, 104746. [CrossRef]

76. Chukhrov, F.V.; Gorshkov, A.I.; Rudnitskaya, E.S.; Beresovskaya, V.V.; Sivtsov, A.V. Manganese minerals in clays: A review. Clays Clay Miner. 1980, 28, 346-354. [CrossRef]

77. Yin, X.; Yu, L.; Luo, X.; Zhang, Z.; Sun, H.; Mosa, A.; Wang, N. Sorption of $\mathrm{Pb}(\mathrm{II})$ onto $<1 \mu \mathrm{m}$ effective diameter clay minerals extracted from different soils of the Loess Plateau, China. Geoderma 2018, 337, 1058-1066. [CrossRef] 
78. Ahmad, Z.; Gao, B.; Mosa, A.; Yu, H.; Yin, X.; Bashir, A.; Ghoveisi, H.; Wang, S. Removal of Cu(II), Cd(II) and Pb(II) ions from aqueous solutions by biochars derived from potassium-rich biomass. J. Clean. Prod. 2018, 180, 437-449. [CrossRef]

79. Leite, C.M.D.C.; Muraoka, T.; Colzato, M.; Alleoni, L.R.F. Soil-applied Zn effect on soil fractions. Sci. Agricola 2020, 77. [CrossRef]

80. Singh, D.; McLaren, R.G.; Cameron, K.C. Effect of pH on Zinc Sorption-Desorption by Soils. Commun. Soil Sci. Plant Anal. 2008, 39, 2971-2984. [CrossRef]

81. Chiroma, T.M.; Ebewele, R.O.; Hymore, F.K. Comparative assessment of heavy metal levels in soil, vegetables and urban grey waste water used for irrigation in Yola and Kano. Int. Refereed J. Eng. Sci. 2014, 3, 1-9.

82. Namazi, R.; Zabihollahi, R.; Behbahani, M.; Rezaei, A. Inhibitory activity of Avicennia marina, a medicinal plant in Persian folk medicine, against HIV and HSV. Iran. J. Pharm. Res. 2013, 12, 435. [PubMed]

83. Abdelgawad, A.A. Tamarix nilotica (Ehrenb) bunge: A review of phytochemistry and pharmacology. J. Microb. Biochem. Technol. 2017, 9, 544-553.

84. Wang, G.; Su, M.-Y.; Chen, Y.-H.; Lin, F.-F.; Luo, D.; Gao, S.-F. Transfer characteristics of cadmium and lead from soil to the edible parts of six vegetable species in southeastern China. Environ. Pollut. 2006, 144, 127-135. [CrossRef] [PubMed]

85. Ghnaya, T.; Slama, I.; Messedi, D.; Grignon, C.; Ghorbel, M.H.; Abdelly, C. Effects of Cd2+ on K+, Ca2+ and N uptake in two halophytes Sesuvium portulacastrum and Mesembryanthemum crystallinum: Consequences on growth. Chemosphere 2007, 67, 72-79. [CrossRef]

86. Han, R.M.; Lefèvre, I.; Albacete, A.; Pérez-Alfocea, F.; Barba-Espín, G.; Díaz-Vivancos, P.; Quinet, M.; Ruan, C.J.; Hernández, J.A.; Cantero-Navarro, E. Antioxidant enzyme activities and hormonal status in response to Cd stress in the wetland halophyte Kosteletzkya virginica under saline conditions. Physiol. Plant. 2013, 147, 352-368. [CrossRef]

87. Ksouri, R.; Falleh, H.; Megdiche, W.; Trabelsi, N.; Mhamdi, B.; Chaieb, K.; Bakrouf, A.; Magné, C.; Abdelly, C. Antioxidant and antimicrobial activities of the edible medicinal halophyte Tamarix gallica L. and related polyphenolic constituents. Food Chem. Toxicol. 2009, 47, 2083-2091. [CrossRef]

88. Demiral, T.; Turkan, I. Comparative lipid peroxidation, antioxidant defense systems and proline content in roots of two rice cultivars differing in salt tolerance. Environ. Exp. Bot. 2005, 53, 247-257. [CrossRef]

89. Asada, K. The water-water cycle in chloroplasts: Scavenging of Active Oxygens and Dissipation of Excess Photons. Annu. Rev. Plant Biol. 1999, 50, 601-639. [CrossRef]

90. Foyer, C.H.; Noctor, G. Redox sensing and signalling associated with reactive oxygen in chloroplasts, peroxisomes and mitochondria. Physiol. Plant. 2003, 119, 355-364. [CrossRef]

91. Zhou, Z.S.; Huang, S.Q.; Guo, K.; Mehta, S.K.; Zhang, P.C.; Yang, Z.M. Metabolic adaptations to mercury-induced oxidative stress in roots of Medicago sativa L. J. Inorg. Biochem. 2007, 101, 1-9. [CrossRef]

92. Yadav, S. Heavy metals toxicity in plants: An overview on the role of glutathione and phytochelatins in heavy metal stress tolerance of plants. S. Afr. J. Bot. 2010, 76, 167-179. [CrossRef]

93. Zhang, W.-H.; Tyerman, S. Inhibition of Water Channels by HgCl2 in Intact Wheat Root Cells1. Plant Physiol. 1999, 120, 849-858. [CrossRef] [PubMed]

94. Apel, K.; Hirt, H. Reactive oxygen species: Metabolism, oxidative stress, and signal transduction. Annu. Rev. Plant Biol. 2004, 55, 373-399. [CrossRef]

95. Ellouzi, H.; Ben Hamed, K.; Hernández, I.; Cela, J.; Müller, M.; Magné, C.; Abdelly, C.; Munné-Bosch, S. A comparative study of the early osmotic, ionic, redox and hormonal signaling response in leaves and roots of two halophytes and a glycophyte to salinity. Planta 2014, 240, 1299-1317. [CrossRef]

96. Kazachkova, Y.; Eshel, G.; Pantha, P.; Cheeseman, J.M.; Dassanayake, M.; Barak, S. Halophytism: What have we learnt from Arabidopsis thaliana relative model systems? Plant Physiol. 2018, 178, 972-988. [CrossRef]

97. Stohs, S.J.; Bagchi, D. Oxidative mechanisms in the toxicity of metal ions. Free. Radic. Biol. Med. 1995, 18, 321-336. [CrossRef]

98. Kruk, J.; Szymańska, R. Singlet oxygen oxidation products of carotenoids, fatty acids and phenolic prenyllipids. J. Photochem. Photobiol. B Biol. 2021, 216, 112148. [CrossRef] [PubMed]

99. Dong, J.; Wu, F.; Zhang, G. Influence of cadmium on antioxidant capacity and four microelement concentrations in tomato seedlings (Lycopersicon esculentum). Chemosphere 2006, 64, 1659-1666. [CrossRef]

100. Eisa, S.; Hussin, S.; Geissler, N.; Koyro, H.W. Effect of $\mathrm{NaCl}$ salinity on water relations, photosynthesis and chemical composition of Quinoa ('Chenopodium quinoa'Willd.) as a potential cash crop halophyte. Aust. J. Crop. Sci. 2012, 6, 357-368.

101. Maricle, B.R.; Lee, R.W.; Hellquist, C.E.; Kiirats, O.; Edwards, G.E. Effects of salinity on chlorophyll fluorescence and $\mathrm{CO}_{2}$ fixation in C4 estuarine grasses. Photosynthetica 2007, 45, 433-440. [CrossRef]

102. Naidoo, G.; Naidoo, Y.; Achar, P. Ecophysiological responses of the salt marsh grass Spartina maritima to salinity. Afr. J. Aquat. Sci. 2012, 37, 81-88. [CrossRef]

103. Koyro, H.-W.; Hussain, T.; Huchzermeyer, B.; Khan, M.A. Photosynthetic and growth responses of a perennial halophytic grass Panicum turgidum to increasing $\mathrm{NaCl}$ concentrations. Environ. Exp. Bot. 2013, 91, 22-29. [CrossRef]

104. Sunil, B.; Saini, D.; Bapatla, R.B.; Aswani, V.; Raghavendra, A.S. Photorespiration is complemented by cyclic electron flow and the alternative oxidase pathway to optimize photosynthesis and protect against abiotic stress. Photosynth. Res. 2019, 139, 67-79. [CrossRef] [PubMed]

105. Yan, Z.; Sun, X.; Xu, Y.; Zhang, Q.; Li, X. Accumulation and Tolerance of Mangroves to Heavy Metals: A Review. Curr. Pollut. Rep. 2017, 3, 302-317. [CrossRef] 